\title{
Describing Phosphorus Sorption Processes on Volcanic Soil in the Presence of Copper or Silver Engineered Nanoparticles
}

\author{
Jonathan Suazo-Hernández ${ }^{1,2}{ }^{\circledR}$, Erwin Klumpp ${ }^{3}$, Nicolás Arancibia-Miranda ${ }^{4,5}$, Patricia Poblete-Grant ${ }^{2}{ }^{(D}$, \\ Alejandra Jara ${ }^{2,6}$, Roland Bol ${ }^{3}$ and María de La Luz Mora ${ }^{2,6, *(\mathbb{C}}$
}

Citation: Suazo-Hernández, J.; Klumpp, E.; Arancibia-Miranda, N.; Poblete-Grant, P.; Jara, A.; Bol, R.; de La Luz Mora, M. Describing Phosphorus Sorption Processes on Volcanic Soil in the Presence of Copper or Silver Engineered Nanoparticles. Minerals 2021, 11, 373. https://doi.org/10.3390/ $\min 11040373$

Academic Editors: Ana Romero-Freire and Hao Qiu

Received: 5 March 2021

Accepted: 29 March 2021

Published: 1 April 2021

Publisher's Note: MDPI stays neutral with regard to jurisdictional claims in published maps and institutional affiliations.

Copyright: (c) 2021 by the authors. Licensee MDPI, Basel, Switzerland. This article is an open access article distributed under the terms and conditions of the Creative Commons Attribution (CC BY) license (https:// creativecommons.org/licenses/by/ $4.0 /)$.
1 Doctoral Program in Science of Natural Resources, Universidad de La Frontera, Av. Francisco Salazar 01145, P.O. Box 54-D, Temuco, Chile; j.suazo06@ufromail.cl

2 Center of Plant, Soil Interaction and Natural Resources Biotechnology, Scientific and Biotechnological Bioresource Nucleus (BIOREN-UFRO), Universidad de La Frontera, Avenida Francisco Salazar, 01145 Temuco, Chile; patty.grant87@gmail.com (P.P.-G.); alejandra.jara@ufrontera.cl (A.J.)

3 Institute of Bio- and Geosciences, Agrosphere (IBG-3), Forschungszentrum Jülich, Wilhelm Johnen Str., 52425 Jülich, Germany; e.klumpp@fz-juelich.de (E.K.); r.bol@fz-juelich.de (R.B.)

4 Faculty of Chemistry and Biology, Universidad de Santiago de Chile, Av. B. O'Higgins, 3363 Santiago, Chile; nicolas.arancibia@usach.cl

5 Center for the Development of Nanoscience and Nanotechnology, CEDENNA, 9170124 Santiago, Chile

6 Department of Chemical Sciences and Natural Resources, Universidad de La Frontera, Av. Francisco Salazar 01145, P.O. Box 54-D, Temuco, Chile

* Correspondence: mariluz.mora@ufrontera.cl; Tel.: +56-4574-4240; Fax: +56-4532-5053

Abstract: Engineered nanoparticles (ENPs) present in consumer products are being released into the agricultural systems. There is little information about the direct effect of ENPs on phosphorus (P) availability, which is an essential nutrient for crop growth naturally occurring in agricultural soils. The present study examined the effect of 1,3 , and $5 \%$ doses of $\mathrm{Cu}^{0}$ or $\mathrm{Ag}^{0}$ ENPs stabilized with L-ascorbic acid (suspension $\mathrm{pH}$ 2-3) on $\mathrm{P}$ ad- and desorption in an agricultural Andisol with total organic matter (T-OM) and with partial removal of organic matter (R-OM) by performing batch experiments. Our results showed that the adsorption kinetics data of $\mathrm{H}_{2} \mathrm{PO}_{4}{ }^{-}$on T-OM and R-OM soil samples with and without ENPs were adequately described by the pseudo-second-order (PSO) and Elovich models. The adsorption isotherm data of $\mathrm{H}_{2} \mathrm{PO}_{4}{ }^{-}$from T-OM and R-OM soil samples following ENPs addition were better fitted by the Langmuir model than the Freundlich model. When the $\mathrm{Cu}^{0}$ or $\mathrm{Ag}^{0}$ ENPs doses were increased, the $\mathrm{pH}$ value decreased and $\mathrm{H}_{2} \mathrm{PO}_{4}{ }^{-}$adsorption increased on T-OM and R-OM. The $\mathrm{H}_{2} \mathrm{PO}_{4}{ }^{-}$desorption (\%) was lower with $\mathrm{Cu}^{0}$ ENPs than $\mathrm{Ag}^{0}$ ENPs. Overall, the incorporation of ENPs into Andisols generated an increase in P retention, which may affect agricultural crop production.

Keywords: adsorption; engineered nanoparticles; organic matter; phosphorus; nutrients; pollution; volcanic soil

\section{Introduction}

In the past decade, the incorporation of engineered nanoparticles (ENPs) into consumer products [1,2] has led to a significant increase in their turnover from $\$ 250$ billion in 2009 to $\$ 3$ trillion in 2020 [3]. Two of the most widely used ENPs in consumer products are metallic copper $\left(\mathrm{Cu}^{0}\right)$ and silver $\left(\mathrm{Ag}^{0}\right)$, due to their antibacterial properties. $\mathrm{Cu}^{0} \mathrm{ENPs}$ are added to biocides, electronics, paints, cosmetics, agrochemicals, ceramics, and film $[1,3,4]$, whereas $\mathrm{Ag}^{0}$ ENPs are used in textiles, air filters, bandages, paints, food storage containers, agrochemicals, deodorants, toothpaste, and household appliances [5]. Thus, as a consequence of extensive and diverse commercial applications, these ENPs can be released into the environment. Soil is the main sink of disposal for most of the released ENPs [6]. Adverse effects on human health and ecosystems may be expected, making it necessary 
to improve our current understanding of environmental risks, fate, transformations and aggregation behaviors of metallic ENPs [7].

The geochemistry of metallic $\mathrm{Cu}^{0}$ and $\mathrm{Ag}^{0}$ ENPs in soils is complex, due to their chemical transformation between $\mathrm{Cu}^{0}, \mathrm{Cu}^{+}$and $\mathrm{Cu}^{2+}$ as well as between $\mathrm{Ag}^{0}$ and $\mathrm{Ag}^{+}$, respectively $[1,4]$, also due to their strong binding capacity to various soil components like clay minerals, organic matter, microorganisms, among others. Transformations of metallic ENPs in soil include oxidation, dissolution, and sulfidation. Over time, $\mathrm{Cu}^{0}$ ENPs can be oxidized in the soil to form $\mathrm{CuO}$ (tenorite) and $\mathrm{Cu}_{2} \mathrm{O}$ (cuprite) nanoparticles with a core-shell structure. Any of these, both forms of copper oxide nanoparticles, can dissolve and release cuprous and/or cupric ions into solution [8]. Meanwhile, the $\mathrm{Ag}^{0}$ ENPs show a slow oxidation process, which can be promoted in acid soils. The metallic ENPs oxidation in soils can be diminished when organic molecules are used as stabilizing agents [9]. Transformation on metallic ENPs is an important consideration to developing risk assessments of ENPs [4,9].

Several studies have intended to determine the effects caused by ENPs on soil properties. In these studies, it has been shown than due to metallic $\mathrm{Cu}^{0}$ and $\mathrm{Ag}^{0}$, ENPs are characterized by a high surface area and chemical reactivity, variable surface charge and chemical transformation [10]. Once in contact with soil, ENPs may therefore modify their structural and physico-chemical properties such as $\mathrm{pH}$, electric conductivity, redox potential, porosity, and hydraulic conductivity [10-12]. This could affect reactions and processes of elements in soil, such as precipitation, dissolution, co-precipitation, complexation, oxidation/reduction, plant uptake, and ad- and desorption. Particularly, ad- and desorption are important because they control the availability and mobility of contaminants and nutrients [10]. In this context, Taghipour and Jalali [13] reported that metal oxide ENPs $\left(\mathrm{Al}_{2} \mathrm{O}_{3}\right.$ and $\mathrm{TiO}_{2}$ ) caused immobilization of phosphorus $(\mathrm{P})$ in calcareous soils from Hamadan, Western Iran, and reduced the bioavailability of $P$.

In volcanic soils (Andisol and Ultisol), $\mathrm{P}$ is an essential crop macronutrient and this soil contains between 1000 and $3500 \mathrm{mg} \cdot \mathrm{kg}^{-1}$ [14]. However, P availability for plant growth is limited because it can form inner-sphere complexes by ligand exchange with surface $-\mathrm{OH}$ and $-\mathrm{OH}_{2}{ }^{+}$groups of soil components like ferrihydrite, imogolite, allophane, and $\mathrm{Al}(\mathrm{Fe})-$ humus complexes [15-17]. Numerous studies have focused on P availability in volcanic soils considering the effects on soils of fertilizers [18], liming [19], microorganisms [20,21], enzymes [22], inorganic/organic ligands [23], specific surface area [24], surface charge [25], organic matter content [26], and $\mathrm{pH}$ and mineralogy [27].

In relation to effects caused by ENPs in volcanic soils, no studies have assessed the influence of metallic ENPs on the adsorption of nutrients. In this context, the aim of this research was to evaluate the effect of $\mathrm{Cu}^{0}$ or $\mathrm{Ag}^{0}$ ENPs on phosphorus sorption processes in volcanic soils and its relationship with organic matter content. Overall, the results provide new information about the implication of ENPs for nutrient availability in soils.

\section{Materials and Methods}

\subsection{Chemicals Used}

The reagents used were $\mathrm{CuCl}_{2} \cdot 2 \mathrm{H}_{2} \mathrm{O}, \mathrm{AgNO}_{3}$, $\mathrm{L}$-ascorbic acid, $\mathrm{KH}_{2} \mathrm{PO}_{4}, \mathrm{KCl}, \mathrm{HCl}$, and $\mathrm{KOH}$ (analytical grade, Merck) and double-distilled water. The $\mathrm{pH}$ electrode (Orion Star A211 pH Benchtop Meter, Thermo Fischer Scientific Beverly, Waltham, MA, USA) was calibrated using standard buffers of 4.01, 7.01, and 10.01 (Hanna, Woonsocket, RI, USA).

\subsection{Synthesis of $C u^{0}$ and $A g^{0}$ ENPS}

$\mathrm{CuCl}_{2} \cdot 2 \mathrm{H}_{2} \mathrm{O}$ and $\mathrm{AgNO}_{3}$ were used for the formation of $\mathrm{Cu}^{0}$, and $\mathrm{Ag}^{0} \mathrm{ENPs}$, respectively, and L-ascorbic acid was added as a reducing and capping agent [28]. $\mathrm{Cu}^{0} \mathrm{ENPs}$ (or $\mathrm{Ag}^{0}$ ENPs) was synthesized by mixing $10.0 \mathrm{mmol} \cdot \mathrm{L}^{-1} \quad \mathrm{CuCl}_{2} \cdot 2 \mathrm{H}_{2} \mathrm{O}$ (or $\left.10.0 \mathrm{mmol} \cdot \mathrm{L}^{-1} \mathrm{AgNO}_{3}\right)$ in $50 \mathrm{~mL}$ double-distilled water. An Erlenmeyer flask $(100 \mathrm{~mL})$, containing the $\mathrm{CuCl}_{2} \cdot 2 \mathrm{H}_{2} \mathrm{O}$ (or $\mathrm{AgNO}_{3}$ ) solution, was heated in a water bath at $80^{\circ} \mathrm{C}$ with magnetic stirring; $50 \mathrm{~mL}$ of L-ascorbic acid $\left(1.0 \mathrm{~mol} \cdot \mathrm{L}^{-1}\right)$ was added dropwise into the flask 
while stirring. The aqueous dispersion of stabilized $\mathrm{Cu}^{0} \mathrm{ENPs}$ (or $\mathrm{Ag}^{0} \mathrm{ENPs}$ ) obtained was kept at $80^{\circ} \mathrm{C}$ for $24 \mathrm{~h}$ and it was finally saved to ambient conditions for later research.

\subsection{Soil Samples}

The soil used was an Andisol belonging to Santa Barbara series from Southern Chile $\left(36^{\circ} 50^{\prime} \mathrm{S} ; 71^{\circ} 55^{\prime} \mathrm{W}\right)$. The soil was collected from the top $20 \mathrm{~cm}$ depth of the soil horizon. The soil was passed through a $<2 \mathrm{~mm}$ mesh sieve and freeze-dried (total organic matter soil sample $=\mathrm{T}-\mathrm{OM})$. For partial removal of organic matter $(\mathrm{OM})$, the T-OM soil sample was treated several times with $\mathrm{H}_{2} \mathrm{O}_{2}$ until adding did not result anymore in air bubbles emanating from the aqueous solution and maintained at $40{ }^{\circ} \mathrm{C}$ in a thermoregulated bath [29]. The resulting sample was then washed four times with double-distilled water (partial removal of OM soil sample $=\mathrm{R}-\mathrm{OM}$ ). Finally, both soil samples were freeze-dried and stored at $4{ }^{\circ} \mathrm{C}$.

\subsection{Characterization of $A g^{0}$ and $C u^{0} E N P S$}

The synthetized $\mathrm{Cu}^{0}$ and $\mathrm{Ag}^{0}$ ENPs were characterized using transmission electron microscopy (TEM) on a Hitachi model HT7700 (Hitachi, Tokyo, Japan) with Olympus camera (Veleta $2000 \times 2000$ ) using high resolution mode at $120 \mathrm{kV}$. The TEM images obtained were analyzed manually to calculate the particle size with the ImageJ program (version 1.50i, Wayne Rasband, National Institute of Health, Bethesda, MD, USA). The ultraviolet-visible (UV-Vis) spectra was recorded with a double-beam Rayleigh UV-2601 spectrophotometer (BRAIC Co. Ltd., Beijing, China) using $1 \mathrm{~cm}$ path length glass cell. The zeta potential ( $\mathrm{ZP})$ of $\mathrm{Cu}^{0}$ and $\mathrm{Ag}^{0}$ ENPs $(25 \mathrm{mg})$ was measured in the presence of $10 \mathrm{~mL} \mathrm{KCl} 0.01 \mathrm{M}$ using a Nano ZS apparatus (Malvern Instruments, Worcestershire, UK) at $20{ }^{\circ} \mathrm{C}$ and the isoelectric point (IEP) was obtained from graphs of $\mathrm{ZP}$ versus $\mathrm{pH}$. The Fourier-transform infrared spectroscopy (FT-IR) were recorded with a $1 \mathrm{~mL}$ of ENPs suspension. FT-IR analysis was realized using a Cary 630 spectrometer (Agilent Technologies, Santa Clara, CA, USA). The transmission spectrum was acquired with $4 \mathrm{~cm}^{-1}$ resolution and the operating range was $600 \mathrm{~cm}^{-1}$ to $4000 \mathrm{~cm}^{-1}$ at atmospheric pressure and $20^{\circ} \mathrm{C}$. The $\mathrm{pH}$ of the suspensions of ENPs was measured with $10 \mathrm{~mL}$ using a $\mathrm{pH}$ Meter.

\subsection{Characterization of Soil Samples}

The morphological characteristics of both soil samples were obtained by scanning electron microscopy with a STEM SU-3500 transmission module (Hitachi, Tokyo, Japan) and the QUANTAX 100 energy-dispersive X-ray spectrometer detector (EDX), (Bruker, Berlin, Germany) was used for the semi-quantitative analysis of the elemental composition ( $\mathrm{Al}, \mathrm{Si}$, and Fe content). $20 \mathrm{mg}$ of each soil sample were deposited onto 300-mesh Formvar/carboncoated grids and were inspected under a high-vacuum. Confocal analysis was performed by laser scanning confocal microscopy (LSCM) using the Olympus Fluoview1000 (Olympus Optical Co., Melville, New York, NY, USA). $50 \mu \mathrm{L}$ of the suspensions were collocated on a microscope slide with a micropipette and the sample was dried on a stove at $40{ }^{\circ} \mathrm{C}$. The total organic carbon (TOC) of T-OM and R-OM soil samples was calculated using a Shimadzu TOC-V CPH instrument (Shimadzu, Tokyo, Japan). The TOC was transformed into soil organic matter content using the conversion factor of 1.72 [30]. The specific surface area of R-OM and T-OM soils was obtained using the Brunauer, Emmett and Teller (BET) theory. Approximately $200 \mathrm{mg}$ of soil sample was degassed for $2 \mathrm{~h}$ at $105^{\circ} \mathrm{C}$ and then was conducted using $\mathrm{N}_{2}$ gas at $-196{ }^{\circ} \mathrm{C}$ in the relative pressure range $(\mathrm{P} / \mathrm{P} 0)$ of 0.05-0.4. Surface area measurements were made with a Quantachrome Nova 1000e analyzer (Quantachrome Instruments, Boynton Beach, FL, USA). The average pore volume and size were obtained using the Barrett-Joyner-Halenda (BJH) model. For the FT-IR absorption spectrum, soil samples were dried at $50{ }^{\circ} \mathrm{C}$ for $12 \mathrm{~h}$ to eliminate the interference produced by the absorption of the water molecules. To determine the functional groups in both soil samples, the analysis was performed under similar conditions to the ENPs. Soil pH was determined in 1:2.5 soil: double-distilled water ratio after 5 min shaking and $120 \mathrm{~min}$ 
resting, using the same $\mathrm{pH}$ Meter used for ENPs determination. Total $\mathrm{P}$ was extracted from the soil samples by alkaline oxidation with sodium hypobromite $(\mathrm{NaBrO})$ [31]. After each extraction, the supernatant was filtered (5C, Advantec) and then the concentration of total $P$ in the supernatant was determined using a spectrophotometer Rayleigh UV-2601 with a wavelength of $880 \mathrm{~nm}$ [32]. Exchangeable Al was extracted with $\mathrm{KCl}(1 \mathrm{M})$ and measured using a Unicam model Solaar 969 atomic absorption spectrophotometer (AAS) (Unicam Ltd, Cambridge, UK). Exchangeable base cations ( $\mathrm{Na}, \mathrm{K}, \mathrm{Mg}$ and $\mathrm{Ca}$ ) in soils were extracted using $\mathrm{NH}_{4} \mathrm{Ac}(1 \mathrm{M}, \mathrm{pH}$ 7.0) and were measured by AAS [33]. Effective cation exchange capacity (ECEC) was calculated as the sum of exchangeable Al plus the exchangeable base cations [33].

The $\mathrm{ZP}$ and IEP of the soil samples were determined pre- and post-adsorption of $\mathrm{H}_{2} \mathrm{PO}_{4}{ }^{-}$ on T-OM and R-OM soil samples in the absence and presence of $5 \% \mathrm{Cu}^{0}$ or $\mathrm{Ag}^{0} \mathrm{ENPs}$ using the high point adsorption isotherms similar to the procedure followed by ENPs.

\subsection{Adsorption Experiments}

Batch experiments were conducted to investigate the adsorption of phosphate (indicated as $\mathrm{H}_{2} \mathrm{PO}_{4}{ }^{-}$) on T-OM and R-OM soil samples in the absence and presence of $0,1,3$, and $5 \% \mathrm{Cu}^{0}$ or $\mathrm{Ag}^{0}$ ENPs doses $(\% w / w) . \mathrm{Cu}^{0}$ or $\mathrm{Ag}^{0}$ ENPs doses were added to $0.5 \mathrm{~g}$ (dry weight) of soil samples in polyethylene tubes and mixed with $20 \mathrm{~mL} \mathrm{H}_{2} \mathrm{PO}_{4}{ }^{-}$solution. The adsorbed amounts of $\mathrm{H}_{2} \mathrm{PO}_{4}{ }^{-}\left(\mathrm{q}_{\mathrm{t}}, \mathrm{mmol} \cdot \mathrm{kg}^{-1}\right)$ were determined as the difference between initial concentration and final concentration of $\mathrm{H}_{2} \mathrm{PO}_{4}{ }^{-}$in the solution (Equation (1)).

$$
\mathrm{q}_{\mathrm{t}}=\frac{\left(\mathrm{C}_{0}-\mathrm{C}_{\mathrm{t}}\right) \mathrm{V}}{\mathrm{w}}
$$

where, $\mathrm{C}_{\mathrm{o}}$ is the initial concentrations of $\mathrm{H}_{2} \mathrm{PO}_{4}{ }^{-}$and $\mathrm{C}_{\mathrm{t}}$ is the concentrations of $\mathrm{H}_{2} \mathrm{PO}_{4}{ }^{-}$ at time $\mathrm{t}$ or the equilibrium concentration $\left(\mathrm{mmol} \cdot \mathrm{L}^{-1}\right), \mathrm{w}$ the weight $(\mathrm{kg})$ of the soil and $\mathrm{V}$ is the volume (L).

To evaluate the $\mathrm{pH}$ effect on the adsorption of $\mathrm{H}_{2} \mathrm{PO}_{4}{ }^{-}$onto T-OM and R-OM soil samples, stock solutions of $6.47 \mathrm{mmol} \cdot \mathrm{L}^{-1}$ of $\mathrm{H}_{2} \mathrm{PO}_{4}{ }^{-}$were prepared with double-distilled water at $\mathrm{pH}$ ranging from 4.5 to 8.5 by adding $0.1 \mathrm{M} \mathrm{HCl}$ or $\mathrm{KOH}$ and ionic strength $0.01 \mathrm{M}$ $\mathrm{KCl}$ (background electrolyte). The $\mathrm{H}_{2} \mathrm{PO}_{4}{ }^{-}$solutions were added to soil samples with and without ENPs and were stirred at $200 \mathrm{rpm}$ for $24 \mathrm{~h}$ at $20 \pm 2{ }^{\circ} \mathrm{C}$.

For the kinetic study, the initial solution of $6.47 \mathrm{mmol} \cdot \mathrm{L}^{-1}$ of $\mathrm{H}_{2} \mathrm{PO}_{4}{ }^{-}$was adjusted to $\mathrm{pH} 5.5 \pm 0.2$ by adding $0.1 \mathrm{M} \mathrm{HCl}$ or $\mathrm{KOH}$ at ionic strength $0.01 \mathrm{M} \mathrm{KCl}$ and $20 \pm 2{ }^{\circ} \mathrm{C}$. Samples were taken from the suspension at 2.5, 5, 10, 30, 45, 60, 120, 180, 360, 720, and $1440 \mathrm{~min}$, and $\mathrm{H}_{2} \mathrm{PO}_{4}{ }^{-}$was determined in solution. Furthermore, the initial $\mathrm{pH}\left(\mathrm{pH}_{\mathrm{i}}\right)$ and the final $\mathrm{pH}\left(\mathrm{pH}_{\mathrm{f}}\right)$ were measured after $\mathrm{H}_{2} \mathrm{PO}_{4}{ }^{-}$solution was added to soil samples (time 0 min) and after $\mathrm{H}_{2} \mathrm{PO}_{4}{ }^{-}$adsorption (1440 min), respectively.

Adsorption isotherms were obtained by varying the initial $\mathrm{H}_{2} \mathrm{PO}_{4}{ }^{-}$concentrations from 0.016 to $9.71 \mathrm{mmol} \cdot \mathrm{L}^{-1}$ and were initially adjusted to $\mathrm{pH} 5.5 \pm 0.2$ and ionic strength $0.01 \mathrm{M} \mathrm{KCl}$. The suspensions were stirred at $200 \mathrm{rpm}$ in an orbital shaker at $20 \pm 2 \mathrm{C}$ for $24 \mathrm{~h}$. To determine the effect of copper $\left(\mathrm{Cu}^{2+}\right)$ or silver cations $\left(\mathrm{Ag}^{+}\right)$or L-ascorbic acid on $\mathrm{H}_{2} \mathrm{PO}_{4}{ }^{-}$adsorption onto T-OM and R-OM soil samples, adsorption isotherms were made in the presence of $3 \% \mathrm{Cu}^{2+}$ or $\mathrm{Ag}^{+}$or L-ascorbic acid $(\% \mathrm{w} / \mathrm{w})$ under the aforementioned experimental conditions.

The desorption experiment was performed once the adsorption isotherm procedure had ended by adding $20 \mathrm{~mL}$ of double-distilled water three times, and the samples were then stirred at $200 \mathrm{rpm}$ in an orbital shaker at $20 \pm 2{ }^{\circ} \mathrm{C}$ for $24 \mathrm{~h}$. The desorption percentages (\%) were calculated by the equation used by Silva-Yumi et al. [34] All the samples of the adsorption experiments were first centrifuged at 10,000 rpm for $10 \mathrm{~min}$, using a centrifuge RC-5B Plus (Sorvall, Newtown, CT, USA) and then filtered through $0.22 \mu \mathrm{m}$ syringe filters. In all experiments, the concentration of $\mathrm{H}_{2} \mathrm{PO}_{4}{ }^{-}$in the supernatant was determined according to the procedure followed for total P. To minimize manipulation errors in the analysis, the adsorption experiments were performed in triplicate. 


\subsection{Data Analysis}

The kinetics adsorption (e.g., pseudo-first-order, pseudo-second-order, and Elovich) and isotherm (e.g., Langmuir and Freundlich) models used in this study are presented in Tables 1 and 2, respectively.

Table 1. The kinetic models used for the description of phosphate adsorption.

\begin{tabular}{|c|c|c|c|}
\hline Kinetic Equations & Expression Formula & Parameters & References \\
\hline Pseudo-first-order (PFO) & $\mathrm{q}_{\mathrm{t}}=\mathrm{q}_{\mathrm{e}}\left(1-\mathrm{e}^{-\mathrm{k}_{1} \mathrm{t}}\right)$ & $\begin{array}{c}\mathrm{q}_{\mathrm{t}}=\text { amount of anion adsorbed at any time } \\
\left(\mathrm{mmol} \cdot \mathrm{kg}^{-1}\right)\end{array}$ & \multirow{3}{*}[35,36]{} \\
\hline Pseudo-second-order (PSO) * & $\mathrm{q}_{\mathrm{t}}=\frac{\mathrm{k}_{2} \mathrm{q}_{\mathrm{e}}^{2} \mathrm{t}}{1+\mathrm{k}_{2} \mathrm{q}_{\mathrm{e}} \mathrm{t}}$ & $\begin{array}{c}\mathrm{q}_{\mathrm{e}}=\text { amount of anion adsorbed at equilibrium } \\
\left(\mathrm{mmol} \cdot \mathrm{kg}^{-1}\right) \\
\mathrm{k}_{1}=\text { PFO rate constant }\left(\mathrm{min}^{-1}\right) \\
\mathrm{k}_{2}=\text { PSO rate constant }\left(\mathrm{kg} \cdot \mathrm{mmol} \mathrm{mon}^{-1} \cdot \mathrm{min}^{-1}\right) \\
\mathrm{t}=\text { time }(\mathrm{min})\end{array}$ & \\
\hline Elovich & $\mathrm{q}_{\mathrm{t}}=\frac{1}{\beta} \ln (1+\alpha \beta \mathrm{t})$ & $\begin{array}{c}\alpha=\text { initial rate constant }\left(\mathrm{mmol} \cdot \mathrm{kg}_{-} \cdot \mathrm{min}^{-1}\right) . \\
\beta=\text { number of sites available for the sorption and } \\
\text { desorption constant }\left(\mathrm{mmol} \cdot \mathrm{kg}^{-1}\right) \text {. }\end{array}$ & \\
\hline
\end{tabular}

${ }^{*}$ From PSO initial adsorption rate (h), can be calculated by multiplying $\mathrm{k}_{2} \mathrm{q}_{\mathrm{t}}^{2}\left(\mathrm{mmol} \cdot \mathrm{kg}^{-1} \cdot \mathrm{min}^{-1}\right)$.

Table 2. The isotherm models used for the description of phosphate adsorption.

\begin{tabular}{|c|c|c|c|}
\hline Isotherm Equations & Expression Formula & Parameters & References \\
\hline Langmuir & $\mathrm{q}_{\mathrm{e}}=\frac{\mathrm{q}_{\mathrm{m}} \mathrm{K}_{\mathrm{L}} \mathrm{C}_{\mathrm{e}}}{1+\mathrm{K}_{\mathrm{L}} \mathrm{C}_{\mathrm{e}}}$ & $\begin{array}{c}\mathrm{q}_{\mathrm{e}}=\text { amount of adsorbed anion per unit mass of the adsorbent at } \\
\text { equilibrium }\left(\mathrm{mmol} \cdot \mathrm{kg}^{-1}\right) . \\
\mathrm{q}_{\mathrm{max}}=\text { maximum adsorption capacity }\left(\mathrm{mmol} \cdot \mathrm{kg}^{-1}\right) . \\
\mathrm{C}_{\mathrm{e}}=\text { concentration of anion at equilibrium in the solution } \\
\left(\mathrm{mmol} \cdot \mathrm{L}^{-1}\right) . \\
\mathrm{K}_{\mathrm{L}}=\text { constant related to the affinity }\left(\mathrm{L} \cdot \mathrm{mmol}^{-1}\right) . \\
\mathrm{K}_{\mathrm{F}}=\text { freundlich adsorption coefficient }\left(\left(\mathrm{mmol} \cdot \mathrm{kg}^{-1}\right)\right. \\
\left.\left(\mathrm{L} \cdot \mathrm{kg}^{-1}\right)^{1 / \mathrm{n}}\right) .\end{array}$ & {$[34,37]$} \\
\hline Freundlich & $\mathrm{q}_{\mathrm{e}}=\mathrm{K}_{\mathrm{F}} \mathrm{C}_{\mathrm{e}}^{\frac{1}{\mathrm{n}}}$ & $\mathrm{n}=$ adsorption intensity $(1<\mathrm{n}<10)$ & \\
\hline
\end{tabular}

The data were evaluated through the Chi-square $\left(\chi^{2}\right)$, adding the coefficient of determination $\left(r^{2}\right)$ (Equations (2) and (3)). The lowest $\chi^{2}$ and highest $r^{2}$ values were used as the best fit [37]. The statistical analysis of the adsorption data was conducted using Origin Pro 8.0.

$$
\begin{gathered}
\chi^{2}=\sum \frac{\left(\mathrm{q}_{\mathrm{e}, \text { exp }}-\mathrm{q}_{\mathrm{e}, \mathrm{cal}}\right)^{2}}{\mathrm{q}_{\mathrm{e}, \mathrm{cal}}} \\
\mathrm{r}^{2}=\sum \frac{\left(\mathrm{q}_{\mathrm{e}, \text { mean }}-\mathrm{q}_{\mathrm{e}, \mathrm{cal}}\right)^{2}}{\left(\mathrm{q}_{\mathrm{e}, \mathrm{cal}}-\mathrm{q}_{\mathrm{e}, \text { mean }}\right)^{2}+\left(\mathrm{q}_{\mathrm{e}, \mathrm{cal}}-\mathrm{q}_{\mathrm{e}, \text { exp }}\right)^{2}}
\end{gathered}
$$

where, $\mathrm{q}_{\mathrm{e} \text {,mean }}$ is the average value of experimental adsorption capacity $\left(\mathrm{mmol} \cdot \mathrm{kg}^{-1}\right)$, $\mathrm{q}_{\mathrm{e}, \mathrm{cal}}$ is the equilibrium capacity from a model $\left(\mathrm{mmol} \cdot \mathrm{kg}^{-1}\right)$ and $\mathrm{q}_{\mathrm{e}, \text { exp }}$ is the experimental adsorption capacity.

\section{Results}

\subsection{Characterization of $C u^{0}$ and $A g^{0} E N P s$ and Soils}

The size, morphology, surface charge and the presence of functional groups on the surface of prepared ENPs were determined by TEM images, UV-Vis, ZP and FT-IR analyses. TEM images showed that both ENPs had spherical morphology (Figure S1a,b in Supplementary Materials). $\mathrm{Cu}^{0}$ ENPs had a diameter between 8 and $29 \mathrm{~nm}$, whereas $\mathrm{Ag}^{0}$ ENPs showed a diameter between 7 and $27 \mathrm{~nm}$ (Figure S2a,b). The UV-Vis spectra of $\mathrm{Cu}^{0}$ and $\mathrm{Ag}^{0}$ ENPs showed an extended peak in the range of 342-512 and 337-474 $\mathrm{nm}$, respectively (Figure S3). The FT-IR spectra for pure L-ascorbic acid showed a band 
corresponding to a stretching vibration carbon-carbon double bond at $1674 \mathrm{~cm}^{-1}$ and the peak of enol hydroxyl at $1322 \mathrm{~cm}^{-1}$ (Figure S4a). After the reduction of $\mathrm{Cu}^{2+}$ and $\mathrm{Ag}^{+}$ by L-ascorbic acid, the peaks disappeared and new peaks at $3481 \mathrm{~cm}^{-1}$ and $1636 \mathrm{~cm}^{-1}$ were observed (Figure S4b,c), which were associated with the conjugated hydroxyl and carbonyl groups, respectively. The $\mathrm{pH}$ of $\mathrm{Cu}^{0}$ and $\mathrm{Ag}^{0}$ ENPs suspension was 2.46 and 2.35, respectively. The IEP of $\mathrm{Cu}^{0}$ ENPs was 2.7, whereas $\mathrm{Ag}^{0}$ ENPs had a negatively charged surface in the studied $\mathrm{pH}$ range (Figure S5).

Physico-chemical properties of the soils untreated (T-OM) and treated with $\mathrm{H}_{2} \mathrm{O}_{2}$ (R-OM) are shown in Table 3. The T-OM and R-OM were a typical Andisol exhibiting acidic characteristics showing $\mathrm{pH}$ values of 5.40 (strongly acidic) for T-OM and 6.20 (slightly acidic) for R-OM. Total $\mathrm{P}$ and OM in T-OM were 1.8 and 3.1 times higher as compared to R-OM, whereas the $\mathrm{Al}$ and Fe contents for R-OM were 1.2 and 1.4 times higher than $\mathrm{T}-\mathrm{OM}$. The SEM images revealed a decreased number of aggregates in R-OM compared to T-OM (Figure 1a,b). The contrasting OM content was also indicated in confocal images (Figure $1 \mathrm{c}, \mathrm{d}$ ) by a higher green fluorescence intensity for T-OM as compared to R-OM images. The IEP for T-OM was 3.2, while it was 5.7 for R-OM. Furthermore, the BET-specific surface area and pore volume increased 1.4 and 11.5 times for R-OM in comparison to T-OM. The FT-IR analysis (Figure S6) showed that R-OM had bands at $1003 \mathrm{~cm}^{-1}$ and $913 \mathrm{~cm}^{-1}$ corresponding to alumina and silica-rich allophane, respectively, while T-OM only showed the band at $1003 \mathrm{~cm}^{-1}$ [29]. T-OM had more effective cation exchange capacity (ECEC) than R-OM (Table 3).

Table 3. Physico-chemical properties of soil with total organic matter (T-OM) and with partial removal of matter (R-OM).

\begin{tabular}{ccc}
\hline Parameter & T-OM & R-OM \\
\hline $\mathrm{pH}\left(\mathrm{H}_{2} \mathrm{O}\right)$ & $5.4 \pm 0.0$ & $6.2 \pm 0.0$ \\
Total P $\left(\mathrm{mg} \cdot \mathrm{kg}^{-1}\right)$ & $1766.4 \pm 27.0$ & $996.6 \pm 15.0$ \\
$\mathrm{Si}(\%)$ & $15.9 \pm 3.5$ & $16.3 \pm 2.9$ \\
$\mathrm{Al}(\%)$ & $11.7 \pm 1.1$ & $14.1 \pm 1.5$ \\
$\mathrm{Fe}(\%)$ & $7.5 \pm 0.6$ & $10.5 \pm 1.2$ \\
$\mathrm{OM}(\%)$ & $14.1 \pm 0.1$ & $4.6 \pm 0.1$ \\
ECEC $\left(\mathrm{cmol}(+) \mathrm{kg}^{-1}\right)^{*}$ & $8.8 \pm 0.5$ & $7.8 \pm 0.0$ \\
Isoelectric point & 3.2 & 5.7 \\
BET- specific surface area $\left(\mathrm{m}^{2} \cdot \mathrm{g}^{-1}\right)$ & 17.4 & 24.4 \\
Average pore volume $\left(\mathrm{cm}^{3} \cdot \mathrm{g}^{-1}\right)$ & 0.002 & 10.4 \\
Average pore diameter $(\mathrm{A})$ & 10.7 & 10.4 \\
\hline
\end{tabular}

*ECEC: Effective cation exchange capacity.

\section{2. $\mathrm{H}_{2} \mathrm{PO}_{4}{ }^{-}$Adsorption on Soils with and without $\mathrm{Cu}^{0}$ or $\mathrm{Ag}^{0}$ ENPs}

3.2.1. Effect of $\mathrm{pH}$ Solution

Figure 2 shows the effect of the $\mathrm{H}_{2} \mathrm{PO}_{4}^{-} \mathrm{pH}$ solution between 4.5-8.5 on $\mathrm{H}_{2} \mathrm{PO}_{4}{ }^{-}$ adsorption on T-OM and R-OM soil samples in the absence and presence of ENPs. The $\mathrm{H}_{2} \mathrm{PO}_{4}{ }^{-}$adsorbed on T-OM decreased slightly with increasing $\mathrm{pH}$ without and with ENPs. When $\mathrm{Cu}^{0}$ or $\mathrm{Ag}^{0}$ ENPs content increased, the $\mathrm{H}_{2} \mathrm{PO}_{4}{ }^{-}$adsorption on T-OM was 1.4-1.8 times higher than without ENPs (Figure 2a,c). In addition, the $\mathrm{H}_{2} \mathrm{PO}_{4}{ }^{-}$adsorption on R-OM increased with increased $\mathrm{Cu}^{0}$ ENPs doses, but with $\mathrm{Ag}^{0}$ ENPs showed no changes (Figure 2b,d). 

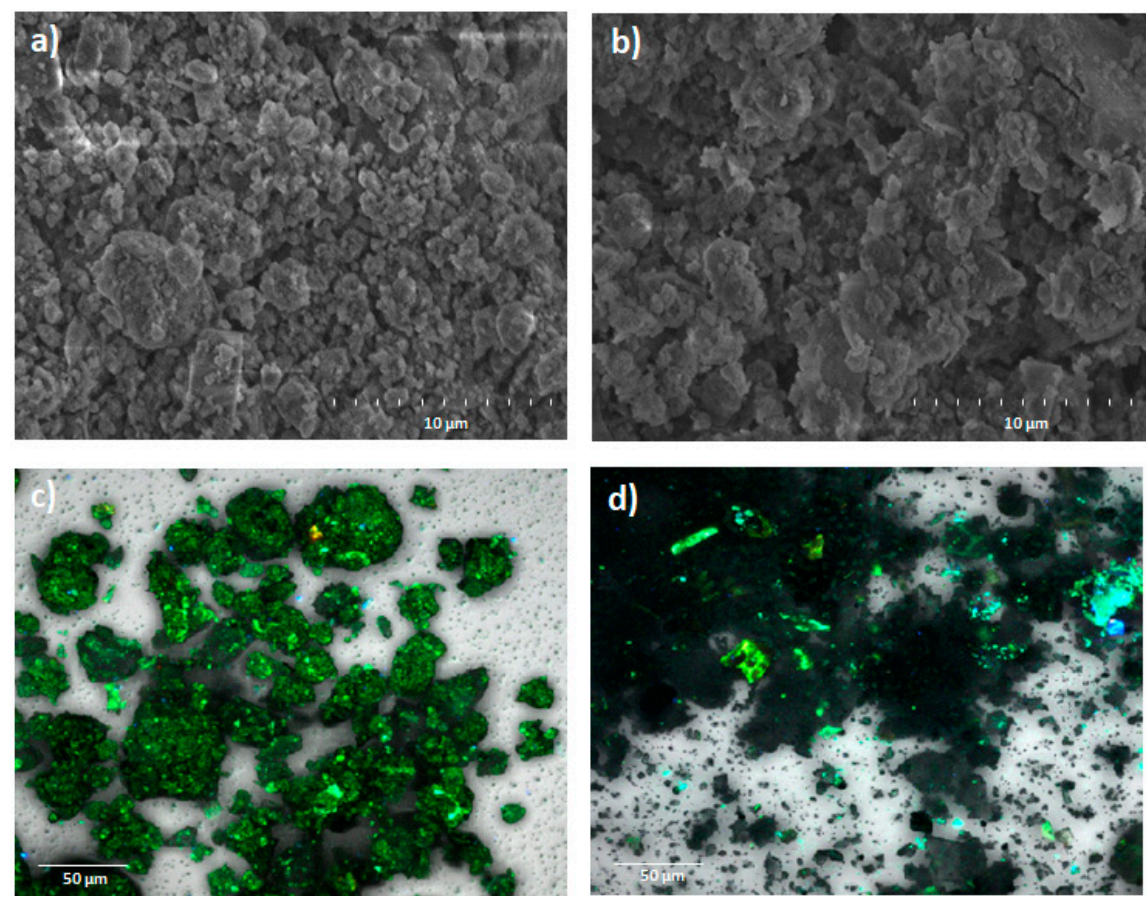

Figure 1. SEM analysis to soil with (a) total organic matter (T-OM) and (b) partial removal of organic matter (R-OM) and confocal images to soil with (c) T-OM and (d) R-OM.
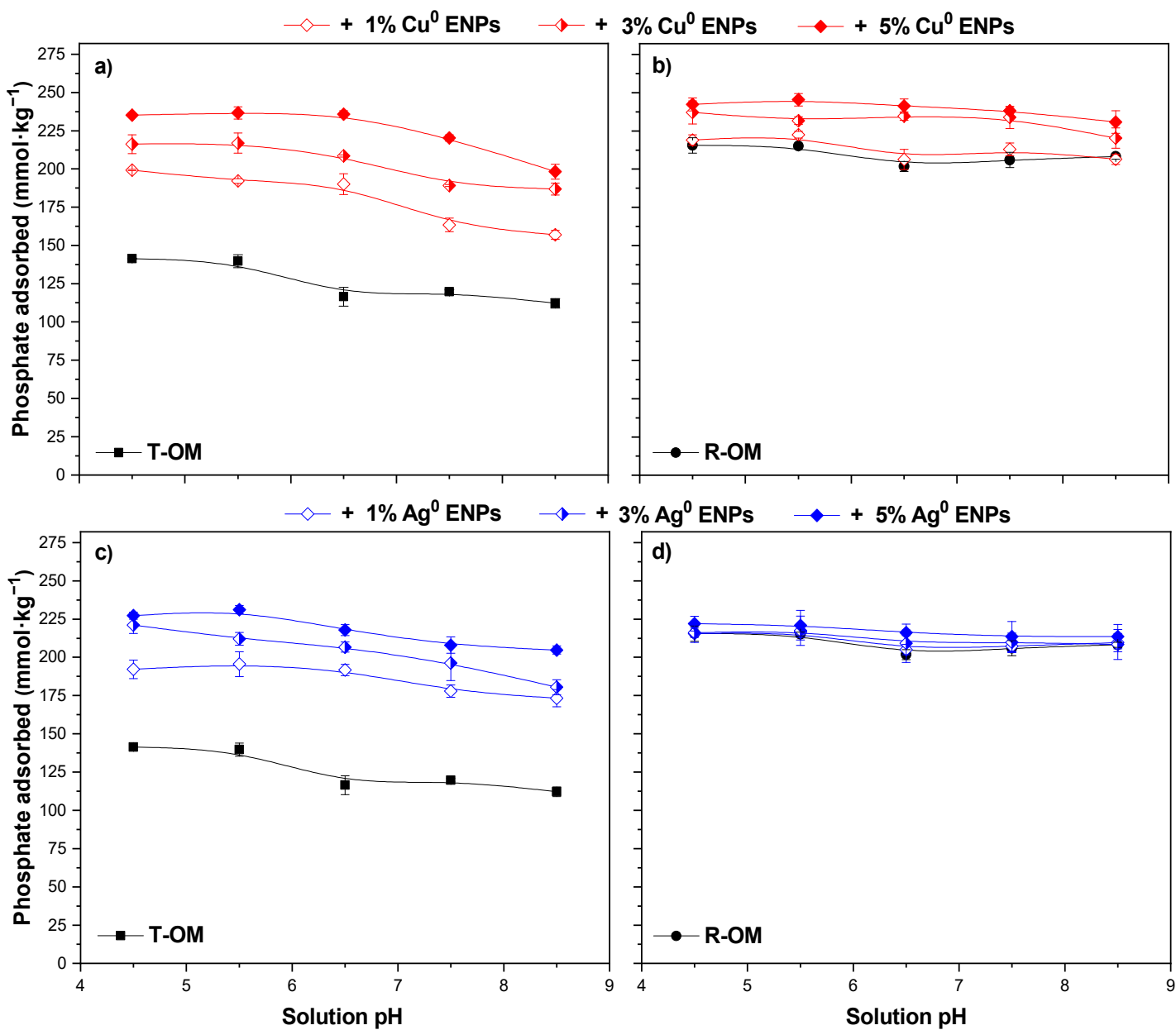

Figure 2. Initial $\mathrm{pH}$ effect of the solution on the adsorption of $\mathrm{H}_{2} \mathrm{PO}_{4}{ }^{-}$in the presence of $\mathrm{Cu}^{0}$ ENPs on soil with (a) total organic matter (T-OM) and (b) partial removal of organic matter (R-OM) and $\mathrm{Ag}^{0}$ ENPs on soil with (c) T-OM and (d) R-OM. 


\subsubsection{Adsorption Kinetics}

The kinetic studies are shown in Figure 3. We observed that increasing in contact time at $\mathrm{pH} 5.5$ as well as in the presence of $\mathrm{Cu}^{0}$ or $\mathrm{Ag}^{0} \mathrm{ENPs}$ there was a subsequent increase in the adsorption of $\mathrm{H}_{2} \mathrm{PO}_{4}{ }^{-}$in T-OM and R-OM soil samples. It was also shown that adsorption comprised a fast initial phase at $45 \mathrm{~min}$, followed by a slower rate stage until equilibrium was reached at $360 \mathrm{~min}$ for T-OM and at $720 \mathrm{~min}$ for R-OM, whereas in the presence of ENPs for most systems it was reached at $720 \mathrm{~min}$. Based on the Table 4, in the absence of ENPs after $\mathrm{H}_{2} \mathrm{PO}_{4}{ }^{-}$adsorption on T-OM and R-OM soil samples, the final $\mathrm{pH}\left(\mathrm{pH}_{\mathrm{f}}\right)$ showed an increase in relation to the initial $\mathrm{pH}\left(\mathrm{pH}_{\mathrm{i}}\right)$. A similar tendency was obtained with increasing the ENPs doses and the $\mathrm{pH}_{\mathrm{i}}$ and $\mathrm{pH}_{\mathrm{f}}$ values were lower compared with systems without ENPs.
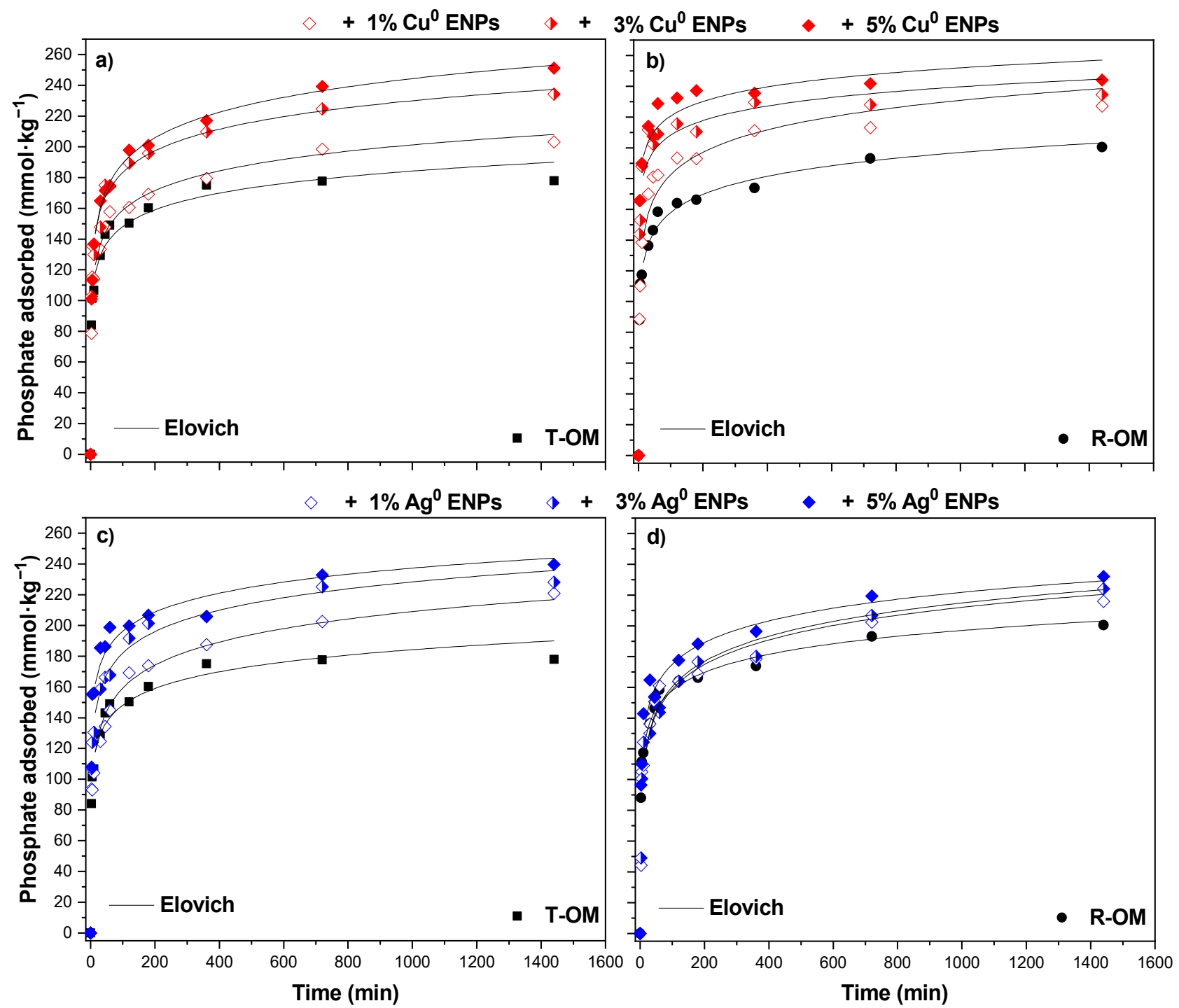

Figure 3. Phosphate adsorption kinetics at $\mathrm{pH} 5.5 \pm 0.2$ of the solution in the presence of $\mathrm{Cu}^{0} \mathrm{ENPs}$ on soil with (a) total organic matter (T-OM) and (b) partial removal of organic matter (R-OM) and $\mathrm{Ag}^{0}$ ENPs on soil with (c) T-OM and (d) R-OM modelled by the Elovich model. 
Table 4. $\mathrm{pH}$ changes associated to $\mathrm{H}_{2} \mathrm{PO}_{4}{ }^{-}$adsorption in the absence and presence of different doses of $\mathrm{Cu}^{0}$ or $\mathrm{Ag}^{0}$ ENPs and two levels of soil organic matter content (total organic matter, T-OM and partial removal of organic matter, R-OM). Experimental conditions: $6.47 \mathrm{mmol} \cdot \mathrm{L}^{-1} \mathrm{H}_{2} \mathrm{PO}_{4}{ }^{-}$solution at $\mathrm{pH} 5.5,0.01 \mathrm{M} \mathrm{KCl}$ at $20 \pm 2{ }^{\circ} \mathrm{C}$. Initial $\mathrm{pH}\left(\mathrm{pH}_{\mathrm{i}}\right)$ and final $\mathrm{pH}\left(\mathrm{pH}_{\mathrm{f}}\right)$ were measured after $\mathrm{H}_{2} \mathrm{PO}_{4}{ }^{-}$solution added to soil samples (time $0 \mathrm{~min}$ ) and after $\mathrm{H}_{2} \mathrm{PO}_{4}{ }^{-}$adsorption (1440 $\mathrm{min})$, respectively.

\begin{tabular}{|c|c|c|c|c|c|c|c|c|c|c|c|c|c|c|}
\hline & & & \multicolumn{6}{|c|}{$\mathrm{Cu}^{0}$ ENPs } & \multicolumn{6}{|c|}{$\mathrm{Ag}^{0}$ ENPs } \\
\hline & \multicolumn{2}{|c|}{$0 \%$} & \multicolumn{2}{|c|}{$1 \%$} & \multicolumn{2}{|c|}{$3 \%$} & \multicolumn{2}{|c|}{$5 \%$} & \multicolumn{2}{|c|}{$1 \%$} & \multicolumn{2}{|c|}{$3 \%$} & \multicolumn{2}{|c|}{$5 \%$} \\
\hline & $\mathrm{pH}_{\mathrm{i}}$ & $\mathrm{pH}_{\mathrm{f}}$ & $\mathrm{pH}_{\mathrm{i}}$ & $\mathrm{pH}_{\mathrm{f}}$ & $\mathrm{pH}_{\mathrm{i}}$ & $\mathrm{pH}_{\mathrm{f}}$ & $\mathrm{pH}_{\mathrm{i}}$ & $\mathrm{pH}_{\mathrm{f}}$ & $\mathrm{pH}_{\mathrm{i}}$ & $\mathrm{pH}_{\mathrm{f}}$ & $\mathrm{pH}_{\mathrm{i}}$ & $\mathrm{pH}_{\mathrm{f}}$ & $\mathrm{pH}_{\mathrm{i}}$ & $\mathrm{pH}_{\mathrm{f}}$ \\
\hline T-OM & $5.4 \pm 0.1$ & $5.7 \pm 0.0$ & $5.0 \pm 0.1$ & $5.4 \pm 0.0$ & $4.3 \pm 0.1$ & $4.7 \pm 0.0$ & $4.0 \pm 0.0$ & $4.2 \pm 0.0$ & $5.0 \pm 0.1$ & $5.6 \pm 0.2$ & $4.5 \pm 0.1$ & $4.9 \pm 0.0$ & $4.2 \pm 0.1$ & $4.7 \pm 0.0$ \\
\hline R-OM & $5.2 \pm 0.0$ & $5.6 \pm 0.1$ & $4.7 \pm 0.1$ & $5.3 \pm 0.1$ & $4.2 \pm 0.0$ & $4.4 \pm 0.0$ & $3.8 \pm 0.0$ & $3.9 \pm 0.0$ & $4.6 \pm 0.1$ & $5.0 \pm 0.1$ & $4.2 \pm 0.0$ & $4.4 \pm 0.0$ & $3.9 \pm 0.0$ & $4.0 \pm 0.0$ \\
\hline
\end{tabular}

To determine the kinetic constants and understand the adsorption mechanisms, the experimental kinetics data were modeled by the pseudo-second-order (PSO) Elovich (Table 5) and pseudo-first-order (PFO) (Table S1) models. PSO and PFO models describe the kinetics of the adsorbate on an adsorbent based on chemical-adsorption and physical-adsorption, respectively, with respect to the adsorbent capacity [36]. On the other hand, the Elovich model describes the sorption of adsorbate onto a heterogeneous surface [38,39].

Based on the higher $\mathrm{r}^{2}$ and the lower $\chi^{2}$ values, the PSO model fitted to the adsorption kinetics data better than the PFO model. According to the PSO model, the amount of $\mathrm{H}_{2} \mathrm{PO}_{4}{ }^{-}$adsorbed at equilibrium $\left(\mathrm{q}_{\mathrm{e}, \mathrm{cal}}\right)$ in T-OM and R-OM soil samples increased with ENPs contents and it was higher in R-OM than T-OM, except for 3 and $5 \% \mathrm{Ag}^{0}$ ENPs doses. The kinetic rate $\left(\mathrm{k}_{2}\right)$ did not show a clear trend at low ENPs contents. However, it increased in T-OM with $5 \% \mathrm{Ag}^{0}$ ENPs and with 3 and $5 \% \mathrm{Cu}^{0}$ ENPs in R-OM as compared to the soils without ENPs. Similar behavior was observed for the initial adsorption rate (h) in the presence of ENPs leading to increases by adding $3 \% \mathrm{Cu}^{0}$ and $5 \% \mathrm{Ag}^{0}$ ENPs for T-OM and R-OM soil samples and $5 \% \mathrm{Cu}^{0}$ for R-OM and $\% \mathrm{Ag}^{0}$ ENPs for T-OM.

Experimental kinetic data at $\mathrm{pH} 5.5$ in T-OM and R-OM soil samples without and with increasing $\mathrm{Cu}^{0}$ or $\mathrm{Ag}^{0}$ ENPs content also adequately fitted the Elovich model $\left(\mathrm{r}^{2}=0.927-0.998\right.$ and $\left.\chi^{2}=9-279\right)$. This means that the $\mathrm{H}_{2} \mathrm{PO}_{4}{ }^{-}$adsorption happened on a heterogeneous substrate [38]. The initial rate $(\alpha)$ and the surface coverage $(\beta)$ obtained from this model showed a similar tendency to $h$ and $k_{2}$, respectively, calculated from the PSO model. Thus, both PSO and Elovich models were capable of describing the kinetics of $\mathrm{H}_{2} \mathrm{PO}_{4}{ }^{-}$adsorption on volcanic soils. Similar results have been obtained by other researchers for an acid soil [40] and for adsorbents such as biochar [38] and chitosan [41].

\subsubsection{Adsorption Isotherms}

The isotherm adsorptions at $\mathrm{pH} 5.5$ (Figure 4) showed that the amount of $\mathrm{H}_{2} \mathrm{PO}_{4}{ }^{-}$ adsorbed was slightly higher in R-OM than T-OM and $\mathrm{H}_{2} \mathrm{PO}_{4}{ }^{-}$adsorption increased with increasing ENPs contents. In general, all adsorption isotherm described curves type L [42]. This means that a high affinity of $\mathrm{H}_{2} \mathrm{PO}_{4}{ }^{-}$anions exist in both soils. In particular, in $\mathrm{T}-\mathrm{OM}$ samples, the curve reached a strict asymptotic plateau, while in R-OM the curve did not reach it. This difference indicated that the number of adsorption sites in the T-OM sample for $\mathrm{H}_{2} \mathrm{PO}_{4}{ }^{-}$is limited; on the contrary, the $\mathrm{R}-\mathrm{OM}$ sample had a greater number of adsorption sites for $\mathrm{H}_{2} \mathrm{PO}_{4}{ }^{-}$. At the same time, by increasing the $\mathrm{Cu}^{0}$ or $\mathrm{Ag}^{0}$ ENPs content, the curves showed a much less strict plateau for both soil samples, suggesting that the number of available adsorption sites for $\mathrm{H}_{2} \mathrm{PO}_{4}{ }^{-}$increased [42,43]. 


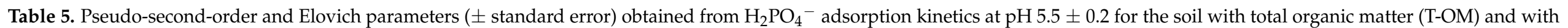
partial removal of organic matter (R-OM) in the absence and presence of different doses of $\mathrm{Cu}^{0}$ or $\mathrm{Ag}^{0} \mathrm{ENPs}$.

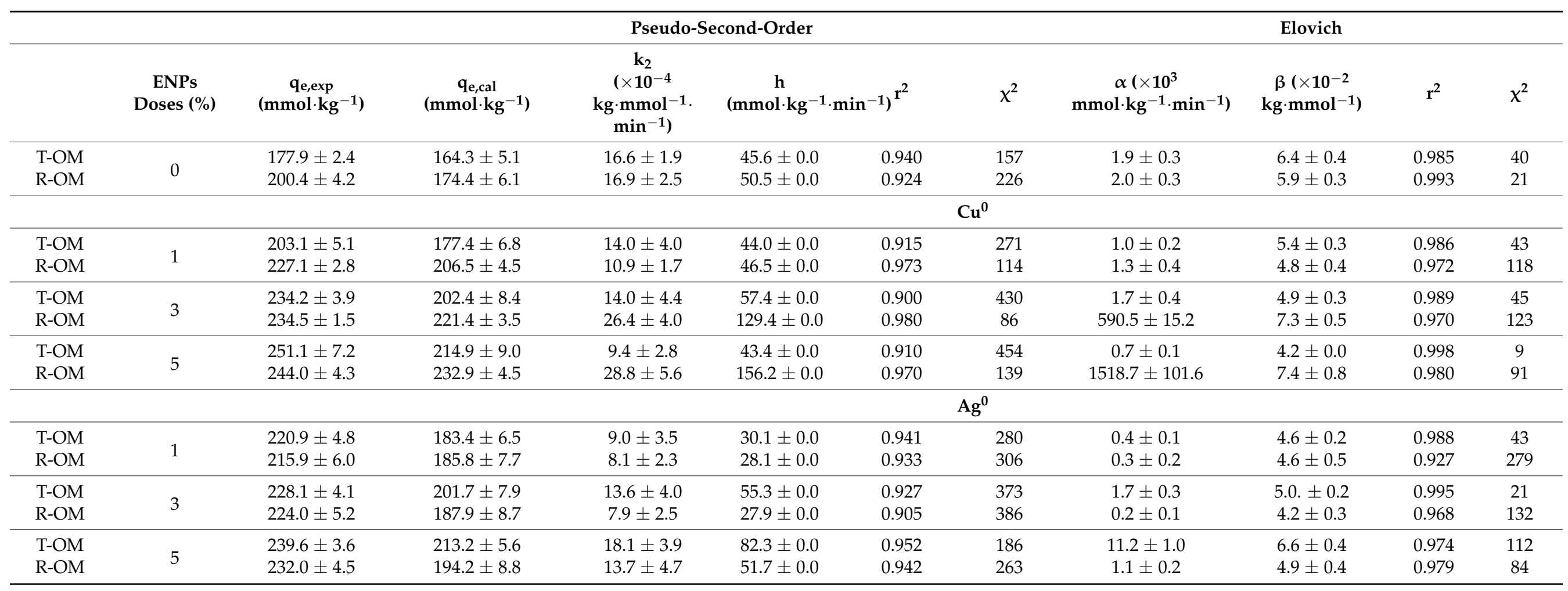




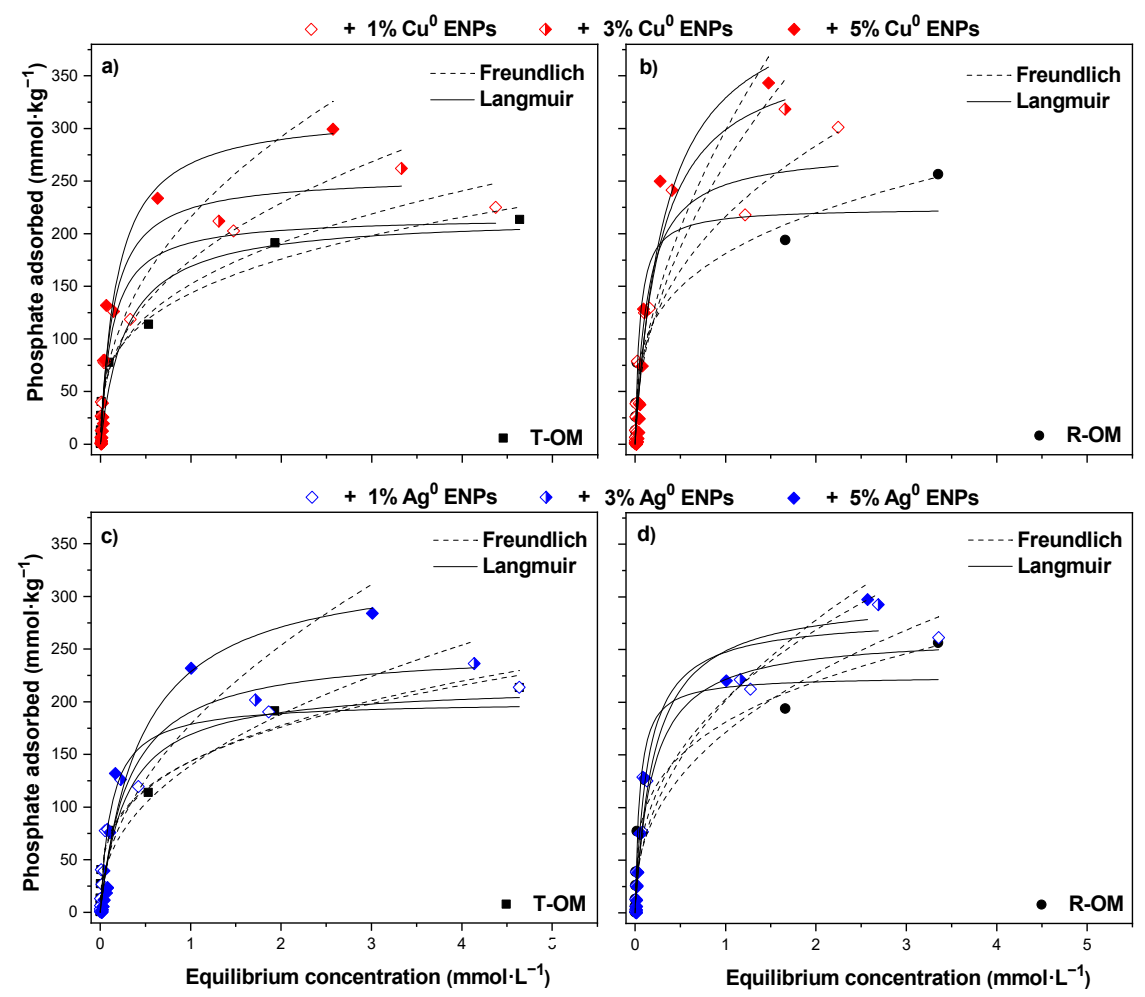

Figure 4. Phosphate adsorption isotherms at $\mathrm{pH} 5.5 \pm 0.2$ of the solutions in the presence of $\mathrm{Cu}^{0} \mathrm{ENPs}$ on soil with (a) total organic matter (T-OM) and (b) partial removal of organic matter (R-OM) and $\mathrm{Ag}^{0}$ ENPs on soil with (c) T-OM and (d) R-OM modelled by the Langmuir and Freundlich models.

The adsorption isotherm data were fitted by Langmuir and Freundlich models (Table 6), which have been frequently used to explain $\mathrm{H}_{2} \mathrm{PO}_{4}{ }^{-}$adsorption on different soils $[44,45]$.

Table 6. Langmuir and Freundlich parameters ( \pm standard error) obtained from $\mathrm{H}_{2} \mathrm{PO}_{4}{ }^{-}$adsorption isotherms at $\mathrm{pH} 5.5 \pm 0.2$ and desorption (\%) for the soil with total organic matter (T-OM) and with partial removal of organic matter (R-OM) in the absence and presence of different doses of $\mathrm{Cu}^{0}$ or $\mathrm{Ag}^{0} \mathrm{ENPs}$.

\begin{tabular}{|c|c|c|c|c|c|c|c|c|c|c|c|}
\hline & \multirow[b]{2}{*}{$\begin{array}{l}\text { ENPs } \\
\text { Doses } \\
(\%)\end{array}$} & \multirow[b]{2}{*}{$\begin{array}{c}\mathrm{q}_{\mathrm{e}, \exp } \\
\left(\mathrm{mmol}^{\left.-\mathrm{kg}^{-1}\right)}\right.\end{array}$} & \multicolumn{4}{|c|}{ Langmuir } & \multicolumn{4}{|c|}{ Freundlich } & \multirow{2}{*}{$\begin{array}{c}\text { Desorption } \\
(\%)\end{array}$} \\
\hline & & & $\begin{array}{c}\mathrm{K}_{\mathrm{L}} \\
\left(\mathrm{L} \cdot \mathbf{m m o l}^{-1}\right)\end{array}$ & $\underset{\left(\mathrm{mmol} \cdot \mathrm{kg}^{-1}\right)}{\mathrm{q}_{\max }}$ & $r^{2}$ & $x^{2}$ & $\begin{array}{c}\mathrm{K}_{\mathrm{F}} \\
\left(\left(\mathrm{mmol}^{\left.-\mathrm{kg}^{-1}\right)}\right)\right. \\
\left.\left(\mathrm{L} \cdot \mathrm{kg}^{-1}\right)^{1 / \mathrm{n}}\right)\end{array}$ & $\mathbf{n}$ & $\mathbf{r}^{2}$ & $x^{2}$ & \\
\hline T-OM & 0 & $213.6 \pm 0.6$ & $3.6 \pm 1.5$ & $216.1 \pm 20.0$ & 0.934 & 396 & $143.5 \pm 5.0$ & $3.4 \pm 0.3$ & 0.982 & 111 & 31.6 \\
\hline \multirow[t]{2}{*}{$\mathrm{R}-\mathrm{OM}$} & & $256.4 \pm 1.4$ & $20.1 \pm 7.3$ & $224.7 \pm 15.6$ & 0.944 & 437 & $181.0 \pm 9.0$ & $3.6 \pm 0.4$ & 0.961 & 299 & 9.7 \\
\hline & & & \multicolumn{9}{|c|}{$\mathrm{Cu}^{0}$} \\
\hline $\mathrm{T}-\mathrm{OM}$ & 1 & $225.0 \pm 1.1$ & $7.8 \pm 3.2$ & $216.2 \pm 16.6$ & 0.943 & 388 & $152.1 \pm 10.6$ & $3.0 \pm 0.4$ & 0.928 & 488 & 24.0 \\
\hline R-OM & & $301.0 \pm 0.7$ & $7.3 \pm 2.8$ & $280.4 \pm 23.2$ & 0.942 & 600 & $216.3 \pm 10.2$ & $2.6 \pm 0.2$ & 0.966 & 352 & 9.5 \\
\hline T-OM & 3 & $262.0 \pm 0.2$ & $7.2 \pm 1.6$ & $255.4 \pm 14.3$ & 0.968 & 274 & $175.0 \pm 13.6$ & $2.6 \pm 0.3$ & 0.923 & 738 & 10.7 \\
\hline $\mathrm{R}-\mathrm{OM}$ & & $318.4 \pm 1.4$ & $3.6 \pm 0.8$ & $382.7 \pm 31.5$ & 0.963 & 434 & $266.8 \pm 25.8$ & $1.9 \pm 0.3$ & 0.870 & 1550 & 6.4 \\
\hline T-OM & 5 & $299.2 \pm 0.5$ & $5.4 \pm 1.5$ & $316.4 \pm 26.1$ & 0.945 & 604 & $216.0 \pm 22.0$ & $2.3 \pm 0.4$ & 0.854 & 1590 & 9.5 \\
\hline \multirow[t]{2}{*}{ R-OM } & & $343.3 \pm 2.4$ & $3.0 \pm 0.9$ & $440.2 \pm 55.3$ & 0.926 & 1000 & $298.2 \pm 33.5$ & $1.9 \pm 0.3$ & 0.836 & 2208 & 4.5 \\
\hline & & & \multicolumn{9}{|c|}{$\mathrm{Ag}^{\mathbf{0}}$} \\
\hline T-OM & 1 & $213.8 \pm 3.0$ & $8.1 \pm 2.7$ & $200.5 \pm 13.3$ & 0.953 & 290 & $143.4 \pm 7.0$ & $3.3 \pm 0.3$ & 0.964 & 219 & 31.5 \\
\hline $\mathrm{R}-\mathrm{OM}$ & & $261.3 \pm 0.3$ & $5.2 \pm 0.8$ & $264.0 \pm 11.4$ & 0.982 & 151 & $171.3 \pm 13.3$ & $2.5 \pm 0.3$ & 0.921 & 724 & 16.8 \\
\hline T-OM & 3 & $236.2 \pm 1.9$ & $3.2 \pm 0.8$ & $249.9 \pm 19.2$ & 0.948 & 361 & $139.9 \pm 14.2$ & $2.3 \pm 0.4$ & 0.870 & 946 & 29.4 \\
\hline R-OM & & $292.7 \pm 2.1$ & $7.3 \pm 1.5$ & $281.4 \pm 15.5$ & 0.970 & 302 & $202.9 \pm 13.0$ & $2.5 \pm 0.3$ & 0.940 & 604 & 21.0 \\
\hline T-OM & 5 & $284.1 \pm 2.8$ & $2.2 \pm 0.6$ & $332.8 \pm 30.8$ & 0.951 & 500 & $178.6 \pm 18.1$ & $2.0 \pm 0.3$ & 0.871 & 1327 & 22.2 \\
\hline $\mathrm{R}-\mathrm{OM}$ & & $297.5 \pm 1.4$ & $4.7 \pm 1.2$ & $301.4 \pm 21.4$ & 0.958 & 434 & $201.5 \pm 15.6$ & $2.2 \pm 0.3$ & 0.924 & 881 & 22.1 \\
\hline
\end{tabular}


The Freundlich model fitted the experimental data of T-OM and R-OM soil samples better than the Langmuir model (Table 6). However, in the presence of ENPs in T-OM and R-OM soil samples, the Langmuir model, except for R-OM-1\% $\mathrm{Cu}^{0} \mathrm{ENPs}$ and $\mathrm{T}-\mathrm{OM}-1 \%$ $\mathrm{Ag}^{0}$ ENPs systems, showed a better fit to the experimental data $\left(\mathrm{r}^{2}=0.926-0.982\right.$ and $\left.\chi^{2}=151-1000\right)$. According to the Langmuir model, the maximum $\mathrm{H}_{2} \mathrm{PO}_{4}{ }^{-}$adsorption capacity $\left(\mathrm{q}_{\max }\right)$ in R-OM and T-OM soils increased with ENPs contents, and it was higher on R-OM than T-OM, except for $5 \% \mathrm{Ag}^{0}$ ENPs dose, in contrast to the affinity coefficient $\left(\mathrm{K}_{\mathrm{L}}\right)$.

\subsubsection{Desorption}

The desorption (\%) depends on the chemical nature and energy of the bonds between soil components and phosphate [46]. In this sense, after the soil samples were treated with double-distilled water repeatedly (three times), $\mathrm{H}_{2} \mathrm{PO}_{4}{ }^{-}$desorption was about 3.2 times higher from T-OM than R-OM (Table 6). In the presence of ENPs, the desorption from R-OM and T-OM soils decreased with increasing $\mathrm{Cu}^{0}$ ENPs doses as well as from T-OM with 3 and $5 \% \mathrm{Ag}^{0}$ ENPs. In contrast, with increasing $\mathrm{Ag}^{0}$ ENPs content, desorption from R-OM was greater than without ENPs.

\section{Discussion}

\subsection{Characterization of $\mathrm{Cu}^{0}$ and $\mathrm{Ag}^{0}$ ENPs and Soil Samples Studied}

The particle size average of $\mathrm{Cu}^{0}(19 \mathrm{~nm})$ and $\mathrm{Ag}^{0}$ ENPs $(17 \mathrm{~nm})$ was low due to L-ascorbic acid coating, which provides colloidal stability to the nanoparticles by electrostatic repulsion. The stability effect of the L-ascorbic acid coating could be attributed to the presence of a polyhydroxyl structure on the surface of both nanoparticles [28]. This was supported by the high negative values of $\mathrm{ZP}$, which is normally related to the negatively charged groups of the capping agents [28,47]. Similar results using organic molecules as reducing and capping agents for the preparation of ENPs have been reported previously [28,47-50].

The organic matter in volcanic soils is highly stabilized [51], whereby after repeated treatment with $\mathrm{H}_{2} \mathrm{O}_{2}$, only a part of the $\mathrm{OM}$ was removed from soil, accounting a $14.1 \%$ of OM (T-OM), obtaining a soil sample with $4.6 \%$ of OM (R-OM) (Table 3 ). The partial removal of OM significantly changed the aggregate structure of the soil because OM acts as a binding agent [52]. In addition, T-OM had more aggregates, a higher P concentration and an effective cation exchange capacity (ECEC) as compared to R-OM. In this sense, it is knowing that the functional groups of OM such as carboxyl, alcoholic hydroxyl, and phenolic hydroxyl contribute to the aggregation of soil particles, formation of humic (organic matter)-Al (Fe)-phosphate complexes and cations adsorption [52,53]. Likewise, R-OM samples had a higher IEP and BET-specific surface area than T-OM. This can be explained by the exposure of $\equiv \mathrm{Fe}-\mathrm{OH}$ and $\equiv \mathrm{Al}-\mathrm{OH}$ active sites from amorphous components of the soil, which decreased the negative charges of the surface and increased BET-specific surface area [34]. In general, allophane and ferrihydrite minerals can interact with negatively charged ENPs through attraction (Van der Waals) forces contributing to their retention in the soil [54].

\subsection{Ad-and Desorption of Phosphate on Soils}

The phosphate adsorption isotherms on T-OM and R-OM soil samples in the absence of ENPs were best fitted to the Freundlich model (Table 6), which reflected the heterogenic nature of soil components. The intensity of adsorption (n) and relative adsorption capacity $\left(\mathrm{K}_{\mathrm{F}}\right)$ for $\mathrm{R}-\mathrm{OM}$ were higher than T-OM. The difference between $\mathrm{K}_{\mathrm{F}}$ and $\mathrm{n}$ for two soil samples may be due to the higher OM content of T-OM, since OM could block adsorption-specific sites leading to a lower availability of surface-reactive sites and weak interaction with $\mathrm{H}_{2} \mathrm{PO}_{4}{ }^{-}$[55]. The $\mathrm{OM}$ can act by preventing the irreversible retention of $\mathrm{H}_{2} \mathrm{PO}_{4}{ }^{-}$and increasing the nutrient recovery. We found that, after partial OM removal, the $\mathrm{H}_{2} \mathrm{PO}_{4}^{-}$desorption from R-OM was lower than from T-OM (Table 6), indicating a strong interaction between the phosphate and mineral components of R-OM [15,16,23]. These 
results are supported by the higher BET-specific surface area and lower negative surface charge of R-OM as compared to T-OM. Similar results were obtained by Zeng et al. [56] for $\mathrm{H}_{2} \mathrm{PO}_{4}{ }^{-}$desorption in volcanic soils exhibiting contrasting OM contents. However, these findings were in contrast to the results reported by Debicka et al. [57] by removing the $\mathrm{OM}$ from sandy soil resulted in decreases of $\mathrm{K}_{\mathrm{F}}$ and $\mathrm{n}$ values. Contrasting results could be attributed to the particularly components in each soil. According to the FAO-WRB soil classification, sandy soils such as Brunic Arenosols are mainly characterized by minerals such as hematite, goethite, and maghemite $[57,58]$. On the contrary, Santa Barbara soil is formed by minerals such as allophane $(>50 \%)$, followed by $1-5 \%$ halloysite and vermiculite [59]. In this context, Parfitt [60] found that phosphate was adsorbed in the order hematite goethite $<$ ferrihydrite $<$ allophane. Moreover, $\mathrm{H}_{2} \mathrm{PO}_{4}{ }^{-}$can be rapidly and strongly adsorbed on the most reactive aluminol $(\equiv \mathrm{Al}-\mathrm{OH})$ groups of the allophane by ligand exchange forming monodentate or/and binuclear complexes.

According to the PSO model, the higher $\mathrm{H}_{2} \mathrm{PO}_{4}{ }^{-}$adsorption $\left(\mathrm{q}_{\mathrm{e}, \mathrm{cal}}\right)$ was in the ROM as compared to T-OM (Table 5), which could due to the destruction of OM in T-OM, leading to a larger pore volume and BET-surface area. In addition, R-OM improved the accessibility to active sites for $\mathrm{H}_{2} \mathrm{PO}_{4}{ }^{-}$according to the higher values of $\alpha$ and $\mathrm{h}$ obtained for R-OM (Table 5) [57]. The h parameter can be associated to the chemical and/or hydrogen bonding interaction between $\mathrm{H}_{2} \mathrm{PO}_{4}{ }^{-}$and surface hydroxyls in soil samples at the initial adsorption process [16]. Moreover, considering the Elovich model and increase in $\mathrm{pH}_{\mathrm{f}}$ values after $\mathrm{H}_{2} \mathrm{PO}_{4}{ }^{-}$adsorption with respect to $\mathrm{pH}_{\mathrm{i}}$ (Table 4), we might suggest that $\mathrm{H}_{2} \mathrm{PO}_{4}{ }^{-}$adsorption in T-OM and R-OM soil samples was performed mainly through ligand exchange (chemi-adsorption) onto $\mathrm{Fe} / \mathrm{Al}$ (hydr)oxides forming monodentate or bidentate complexes. The $\mathrm{pH}$ changes were consistent with the studies carried out by Vistoso et al. [24], who reported that $\mathrm{H}_{2} \mathrm{PO}_{4}{ }^{-}$was adsorbed through ligand exchange mechanism in volcanic soils with contrasting properties.

The $\mathrm{H}_{2} \mathrm{PO}_{4}{ }^{-}$adsorption on T-OM was $\mathrm{pH}$-dependent in contrast to $\mathrm{R}-\mathrm{OM}$ (Figure 2). In this context, the IEP of T-OM was 3.2 whereas it was 5.7 for R-OM. Therefore, in acidic $\mathrm{pH}$ $\mathrm{H}_{2} \mathrm{PO}_{4}{ }^{-}$solution the surface hydroxyl $(-\mathrm{OH})$ groups in R-OM were more protonated than in T-OM, causing a favorable effect on electrostatic interaction and ligand exchange [61]. However, at alkaline $\mathrm{pH} \mathrm{H}_{2} \mathrm{PO}_{4}{ }^{-}$solution, mainly for $\mathrm{T}-\mathrm{OM}$, there was a decrease in the ligand exchange and an increase in electrostatic repulsion due to deprotonation from soil superficial groups. Likewise, at a higher $\mathrm{pH}$, the competition between $\mathrm{OH}^{-}$and $\mathrm{H}_{2} \mathrm{PO}_{4}{ }^{-}$ on the T-OM surface would also reduce the $\mathrm{H}_{2} \mathrm{PO}_{4}{ }^{-}$adsorption [62].

\subsection{Ad-and Desorption of Phosphate on Soils in the Presence of $\mathrm{Cu}$ or $\mathrm{Ag}^{0}$ ENPs}

The increasing phosphate adsorption with increasing ENPs content in soils indicated that in the presence of ENPs, the number of adsorption sites increased. Although, there was a decrease in the initial adsorption rate $(\mathrm{h})$ with $1 \%$ ENPs content, which implied that during the first few minutes ENPs compete with $\mathrm{H}_{2} \mathrm{PO}_{4}{ }^{-}$for the adsorption sites of the soil surface. Additionally, h strongly increased with 3 and $5 \%$ ENPs content, suggesting that ENPs also contributed to new adsorption sites for $\mathrm{H}_{2} \mathrm{PO}_{4}{ }^{-}[63,64]$. Accordingly, Duncan and Owens [63] indicated that $\mathrm{CeO}_{2}$ ENPs can be adsorbed on soil adsorption sites before $\mathrm{Pb}$ (II) and Sun et al. [64] determined a similar trend for $\mathrm{h}$ with increasing carbon nanotubes (CNTs) content after studying the effects of CNTs with outer diameter of $25 \mathrm{~nm}$ and inner diameter of $5 \mathrm{~nm}$ on $\mathrm{Cd}$ (II) adsorption in sediments.

The adsorption isotherms of $\mathrm{H}_{2} \mathrm{PO}_{4}{ }^{-}$on T-OM and R-OM following $\mathrm{Cu}^{0}$ or $\mathrm{Ag}^{0}$ ENPs addition fitted to the Langmuir model (Table 6). Similarly, Sun et al. [64] found that in the presence of CNTs the isotherms for Cd(II) on sediment showed a better fit to the Langmuir than the Freundlich model; however due to the adsorption sites of sediments with CNTs are heterogeneous, they used the Freundlich to describe their results. Therefore, the fit of adsorption data to the Langmuir model in the presence of ENPs should be more studied.

Adsorption enhancement was larger through $\mathrm{Cu}^{0}$ than $\mathrm{Ag}^{0}$ ENPs. According to Afshinnia and Baalousha [65], the decrease in the zeta potential after $\mathrm{H}_{2} \mathrm{PO}_{4}{ }^{-}$adsorption 
on T-OM and R-OM soil samples with ENPs could be associated with $\mathrm{H}_{2} \mathrm{PO}_{4}{ }^{-}$adsorption/complexation onto the ENPs surface (Figure S7). In this context, Niaura et al. [66] indicated that $\mathrm{H}_{2} \mathrm{PO}_{4}{ }^{-}$was adsorbed through monodentate surface coordination on $\mathrm{Cu}^{0}$ ENPs, while on $\mathrm{Ag}^{0}$ ENPs it was performed through hydrogen bonding $[66,67]$. Although both coated ENPs had a low rate of oxidation and dissolution [68], it was probable that these processes could be favored by an acidic soil $\mathrm{pH}$ as well as a consequence of the ionic exchange between $\mathrm{H}_{2} \mathrm{PO}_{4}{ }^{-}$and L-ascorbic acid on the surface of the ENPs, being similar to the mechanism observed for citric acid [50]. Under such conditions, $\mathrm{Cu}^{0}$ could be oxidized to $\mathrm{Cu}^{2+}\left(\mathrm{E}^{\circ} \mathrm{Cu} 2+/ \mathrm{Cu} 0=0.337 \mathrm{~V}\right)$ and the amount of phosphate adsorbed in T-OM and R-OM soil samples increased (Figure S8) because $\mathrm{Cu}^{2+}$ could be linked to $\mathrm{H}_{2} \mathrm{PO}_{4}{ }^{-}$and hydroxyl groups of OM via a cation bridge [69]. Furthermore, this could be attributed to the formation of complexes between $\mathrm{Cu}^{2+}$ and $\mathrm{H}_{2} \mathrm{PO}_{4}{ }^{-}$and the precipitate of $\mathrm{Cu}_{3}\left(\mathrm{PO}_{4}\right)_{2}$ $\left(\mathrm{Ksp}=2.07 \times 10^{-33}\right)$ [70]. Meanwhile, in the case that $\mathrm{Ag}^{+}$ions were released from $\mathrm{Ag}^{0}$ ENPs into solution $\left(\mathrm{E}^{\circ} \mathrm{Ag}+/ \mathrm{Ag} 0=0.799 \mathrm{~V}\right)$, the formation of $\mathrm{AgCl}$ precipitate was more favorable $\left(\mathrm{Ksp}=1.77 \times 10^{-10}\right)$ than a $\mathrm{Ag}_{3} \mathrm{PO}_{4}$ formation $\left(\mathrm{Ksp}=8.89 \times 10^{-17}\right)[71,72]$.

On the other hand, the presence of L-ascorbic acid free in soil solution slightly competes with $\mathrm{H}_{2} \mathrm{PO}_{4}{ }^{-}$for available adsorption sites, decreasing $\mathrm{H}_{2} \mathrm{PO}_{4}{ }^{-}$adsorption on T-OM and R-OM soil samples (Figure S8). However, as a consequence of the addition of $\mathrm{Cu}^{0}$ or $\mathrm{Ag}^{0}$ ENPs suspensions to soil samples, the $\mathrm{pH}_{\mathrm{i}}$ values decreased, being less acidic in T-OM as compared to R-OM (Table 4), which was consistent with the buffering capacity of OM [73]. An acid $\mathrm{pH}$ can be associated with a decrease in the electrostatic repulsion between $\mathrm{H}_{2} \mathrm{PO}_{4}{ }^{-}$and the negatively charged surface of the organic matter $(-\mathrm{COOH},-\mathrm{OH})$ due to a decrease in the number of deprotonated surface groups [74]. Furthermore, the protonation of surface hydroxyl groups of $\mathrm{Fe} / \mathrm{Al}$ (hydr)oxides might be favored by acid $\mathrm{pH}$ values, promoting the $\mathrm{H}_{2} \mathrm{PO}_{4}{ }^{-}$adsorption through a ligand exchange $[24,75,76]$. In the same way, it has been reported that below $4.5 \mathrm{of} \mathrm{pH}$ values the mineral dissolution is favored, promoting the precipitation reactions between $\mathrm{H}_{2} \mathrm{PO}_{4}{ }^{-}$and cations in solution $\left(\mathrm{Al}^{3+}\right.$ and $\left.\mathrm{Fe}^{3+}\right)$ [77], and to form $\mathrm{H}_{2} \mathrm{PO}_{4}{ }^{-}$-cation-organic matter complexes [53].

The increase of the $\mathrm{H}_{2} \mathrm{PO}_{4}{ }^{-}$adsorption at a low $\mathrm{pH}$ has been demonstrated on pillared bentonites [75], AgNPs-tea activated carbon [76], sediments [78] and in Andisol soils [24]. Future research should be addressed to corroborate whether, in the presence of both ENPs, one of these mechanisms was prevalent for $\mathrm{H}_{2} \mathrm{PO}_{4}{ }^{-}$adsorption on T-OM and R-OM soil samples, or whether several mechanisms acted together.

The $\mathrm{H}_{2} \mathrm{PO}_{4}{ }^{-}$adsorption in the presence of ENPs through chemical interactions onto a heterogeneous surface was indicated by the adequate fits of the kinetic data to the PSO and Elovich models (Table 5). In addition, the desorption behavior supported the adsorption mechanisms proposed in the presence of ENPs. With $\mathrm{Cu}^{0} \mathrm{ENPs}$, the desorption of $\mathrm{H}_{2} \mathrm{PO}_{4}{ }^{-}$ from T-OM and R-OM soil samples was smaller than $\mathrm{Ag}^{0}$ ENPs. These results can be supported by a chemisorption-like interaction between $\mathrm{H}_{2} \mathrm{PO}_{4}{ }^{-}$and $\mathrm{Cu}^{0}$ ENPs. Similarly, desorption studies of $\mathrm{U}(\mathrm{VI})$ on the soil in the presence of nano-crystalline goethite showed that $\mathrm{U}(\mathrm{VI})$ was more resistant to released due to an increase in the inner-sphere complexes on the soil surface [79]. In addition, Elkhatib et al. [80] revealed that sorption of $\mathrm{Hg}$ (II) on arid soils in the presence of water treatment residual nanoparticles occurred mainly through inner-sphere complexes, which enhanced $\mathrm{Hg}$ immobilization in the arid soils. The high desorption of $\mathrm{H}_{2} \mathrm{PO}_{4}{ }^{-}$in R-OM following $\mathrm{Ag}^{0}$ ENPs addition needs further investigation. One possible explanation for this is that the $\mathrm{Ag}^{0}$ ENPs were attached to the potential $\mathrm{H}_{2} \mathrm{PO}_{4}{ }^{-}$adsorption sites, such as allophane and Fe oxides, leading to a blocking effect for $\mathrm{H}_{2} \mathrm{PO}_{4}{ }^{-}$on this soil with lower levels of OM. Then, the $\mathrm{H}_{2} \mathrm{PO}_{4}{ }^{-}$physi-adsorbed (through hydrogen bonding) on the surface of the attached $\mathrm{Ag}^{0}$ ENPs was more desorbable.

\section{Conclusions}

Our study demonstrated that the phosphate adsorption process in the presence of ENPs was dependent on the amount of ENPs and soil organic matter content. The addition of $\mathrm{Cu}^{0}$ caused a higher increase in phophate adsorpion on T-OM and R-OM as compared to 
the $\mathrm{Ag}^{0}$ ENPs. The Elovich and pseudo-second-order (PSO) models correctly described the kinetic adsorption of phosphate on T-OM and R-OM soil samples without and with ENPs.

The phosphate adsorption with both ENPs was better described by the Langmuir isotherm model than the Freundlich model. According to the Langmuir model, by increasing the ENPs content from 0 to $5 \%$, the maximum adsorption capacity ( $\mathrm{q}_{\max }$ ) of $\mathrm{H}_{2} \mathrm{PO}_{4}{ }^{-}$ for T-OM ranged from 216.1 to $316.4 \mathrm{mmol} \cdot \mathrm{kg}^{-1}$ following the $\mathrm{Cu}^{0}$ ENPs addition and to $332.8 \mathrm{mmol} \cdot \mathrm{kg}^{-1}$ using $\mathrm{Ag}^{0}$ ENPs. Meanwhile, with the increase from 0 to $5 \%$ of ENPs, the $\mathrm{q}_{\max }$ of $\mathrm{H}_{2} \mathrm{PO}_{4}{ }^{-}$for R-OM ranged from 224.7 to $440.2 \mathrm{mmol} \cdot \mathrm{kg}^{-1}$ with $\mathrm{Cu}^{0} \mathrm{ENPs}$ and to $301.4 \mathrm{mmol} \cdot \mathrm{kg}^{-1}$ with $\mathrm{Ag}^{0}$ ENPs. Phosphate desorption in T-OM and R-OM soils following $\mathrm{Cu}^{0}$ ENPs addition was lower than $\mathrm{Ag}^{0}$ ENPs. In the future, more attention should be pointed globally to management agriculture practices based on nanotechnology, because the incorporation of ENPs into the soil have the potential to reduce the already limited crop phosphorus availability.

Supplementary Materials: The following are available online at https:/ /www.mdpi.com/article/10 $.3390 / \min 11040373 / \mathrm{s} 1$, Figure S1: TEM images L-ascorbic acid-stabilized (a) $\mathrm{Cu}^{0}$ and (b) $\mathrm{Ag}^{0}$ ENPs, Figure S2: Histograms with the corresponding particle size distribution for L-ascorbic acid-stabilized (a) $\mathrm{Cu}^{0}$ and (b) $\mathrm{Ag}^{0}$ ENPs, Figure S3: UV-Vis absorption spectra for L-ascorbic acid-stabilized $\mathrm{Cu}^{0}$ and $\mathrm{Ag}^{0}$ ENPs, Figure S4: FT-IR spectra of (a) Pure L-ascorbic acid, (b) L-ascorbic acid-stabilized $\mathrm{Cu}^{0}$ ENPs and (c) L-ascorbic acid-stabilized $\mathrm{Ag}^{0}$ ENPs, Figure S5: Zeta potential of L-ascorbic acidstabilized $\mathrm{Cu}^{0}$ and $\mathrm{Ag}^{0}$ ENPs in $0.01 \mathrm{M} \mathrm{KCl}$, Figure S6: FT-IR spectrum for soil samples with (a) total organic matter (T-OM) and (b) partial removal of organic matter (R-OM), Figure S7: Zeta potential curves in the presence of $9.71 \mathrm{mmol} \cdot \mathrm{L}^{-1} \mathrm{H}_{2} \mathrm{PO}_{4}{ }^{-}$and $5 \% \mathrm{Cu}^{0}$ or $5 \% \mathrm{Ag}^{0}$ ENPs at constant ionic strength $(0.01 \mathrm{M} \mathrm{KCl})$ for soil with (a) total organic matter (R-OM) and (b) partial removal of organic matter (R-OM), Figure S8: Adsorption isotherm curves of $\mathrm{H}_{2} \mathrm{PO}_{4}{ }^{-}$on (a) total organic matter (T-OM) and $/ 9 \mathrm{~b}$ ) partial removal of organic matter (R-OM) in the presence of $3 \% \mathrm{~L}$-ascorbic acid and $\mathrm{Cu}^{2+}$ and $\mathrm{Ag}^{+}$. Reaction conditions: Concentrations from 0.016 to $9.71 \mathrm{mmol} \cdot \mathrm{L}^{-1} \mathrm{H}_{2} \mathrm{PO}_{4}{ }^{-}$on $0.5 \mathrm{~g}$ soil in $0.01 \mathrm{M} \mathrm{KCl}$ at $20 \pm 2{ }^{\circ} \mathrm{C}$ and $\mathrm{pH}$ 5.5, Table S1: Pseudo-first-order parameters ( \pm standard error) obtained from $\mathrm{H}_{2} \mathrm{PO}_{4}{ }^{-}$adsorption kinetics in the absence and presence of different doses of $\mathrm{Cu}^{0}$ and $\mathrm{Ag}^{0}$ ENPs at $\mathrm{pH} 5.5 \pm 0.2$ for soil with total organic matter (T-OM) and with partial removal of organic matter (R-OM).

Author Contributions: Conceptualization, E.K., M.d.L.L.M. and A.J.; methodology, J.S.-H.; software, J.S.-H.; validation, M.d.L.L.M., E.K., N.A.-M. and R.B.; formal analysis, J.S.-H.; P.P.-G. and A.J.; investigation, J.S.-H. and P.P.-G.; resources, M.d.L.L.M.; data curation, J.S.-H.; writing-original draft preparation, J.S.-H., N.A.-M. and E.K.; writing—review and editing, E.K., R.B., N.A.-M. and A.J.; visualization, J.S.-H. and R.B.; supervision, M.d.L.L.M. and N.A.-M.; project administration, M.d.L.L.M.; funding acquisition, M.d.L.L.M. and J.S.-H. All authors have read and agreed to the published version of the manuscript.

Funding: This research was funded by the Fondo Nacional de Desarrollo Científico y Tecnológico (FONDECYT) projects $\mathrm{N}^{\mathrm{o}} 1181050$ and 1191018 and by the Agencia Nacional de Investigación y Desarrollo (ANID) Ph.D. scholarships No 21171685.

Data Availability Statement: Data are contained within this article.

Acknowledgments: Jonathan Suazo-Hernández acknowledges to Daniela Vergara, the FONDECYT project $\mathrm{N}^{\circ} 3210228$, the Technological Bioresource Nucleus (BIOREN-UFRO) and the Soil and Plant Laboratory.

Conflicts of Interest: The authors declare no conflict of interests.

\section{References}

1. Shah, V.; Luxton, T.P.; Walker, V.K.; Brumfield, T.; Yost, J.; Shah, S.; Wilkinson, J.E.; Kambhampati, M. Fate and impact of zero-valent copper nanoparticles on geographically-distinct soils. Sci. Total Environ. 2016, 573, 661-670. [CrossRef]

2. Ramyadevi, J.; Jeyasubramanian, K.; Marikani, A.; Rajakumar, G.; Rahuman, A.A. Synthesis and antimicrobial activity of copper nanoparticles. Mater. Lett. 2012, 71, 114-116. [CrossRef]

3. Roco, M.C.; Mirkin, C.A.; Hersam, M.C. Nanotechnology research directions for societal needs in 2020: Summary of international study. J. Nanoparticle Res. 2011, 13, 897-919. [CrossRef] 
4. Li, M.; Wang, P.; Dang, F.; Zhou, D.M. The transformation and fate of silver nanoparticles in paddy soil: Effects of soil organic matter and redox conditions. Environ. Sci. Nano 2017, 4, 919-928. [CrossRef]

5. Baskar, V.; Venkatesh, J.; Park, S.W. Impact of biologically synthesized silver nanoparticles on the growth and physiological responses in Brassica rapa ssp. pekinensis. Environ. Sci. Pollut. Res. 2015, 22, 17672-17682. [CrossRef]

6. Boxall, A.B.A.; Tiede, K.; Chaudhry, Q. Engineered nanomaterials in soils and water: How do they behave and could they pose a risk to human health? Nanomedicine 2007, 2, 919-927. [CrossRef] [PubMed]

7. Conway, J.R.; Adeleye, A.S.; Gardea-Torresdey, J.; Keller, A.A. Aggregation, dissolution, and transformation of copper nanoparticles in natural waters. Environ. Sci. Technol. 2015, 49, 2749-2756. [CrossRef] [PubMed]

8. Kent, R.D.; Vikesland, P.J. Dissolution and Persistence of Copper-Based Nanomaterials in Undersaturated Solutions with Respect to Cupric Solid Phases. Environ. Sci. Technol. 2016, 50, 6772-6781. [CrossRef]

9. Liu, J.; Hurt, R.H. Ion release kinetics and particle persistence in aqueous nano-silver colloids. Environ. Sci. Technol. 2010, 44, 2169-2175. [CrossRef]

10. Ben-Moshe, T.; Frenk, S.; Dror, I.; Minz, D.; Berkowitz, B. Effects of metal oxide nanoparticles on soil properties. Chemosphere 2013, 90, 640-646. [CrossRef] [PubMed]

11. Bayat, H.; Kolahchi, Z.; Valaey, S.; Rastgou, M.; Mahdavi, S. Iron and magnesium nano-oxide effects on some physical and mechanical properties of a loamy Hypocalcic Cambisol. Geoderma 2019, 335, 57-68. [CrossRef]

12. Torrent, L.; Marguí, E.; Queralt, I.; Hidalgo, M.; Iglesias, M. Interaction of silver nanoparticles with mediterranean agricultural soils: Lab-controlled adsorption and desorption studies. J. Environ. Sci. 2019, 83, 205-216. [CrossRef] [PubMed]

13. Taghipour, M.; Jalali, M. Effect of nanoparticles on kinetics release and fractionation of phosphorus. J. Hazard. Mater. 2015, 283, 359-370. [CrossRef] [PubMed]

14. Escudey, M.; Galindo, G.; Förster, J.E.; Briceño, M.; Diaz, P.; Chang, A. Chemical Forms of Phosphorus of Volcanic Ash-Derived Soils in Chile. Commun. Soil Sci. Plant Anal. 2001, 32, 601-616. [CrossRef]

15. Mora, M.L.; Galindo, G.; Escudey, M. The role of iron oxides and organic matter on phosphate adsorption in model allophanic synthetic soils. Chil. J. Agric. Res. 1992, 52, 416-421.

16. Wang, H.; Zhu, J.; Fu, Q.L.; Xiong, J.W.; Hong, C.; Hu, H.Q.; Violante, A. Adsorption of phosphate onto ferrihydrite and ferrihydrite-humic acid complexes. Pedosphere 2015, 25, 405-414. [CrossRef]

17. Borie, F.; Aguilera, P.; Castillo, C.; Valentine, A.; Seguel, A.; Barea, J.M.; Cornejo, P. Revisiting the Nature of Phosphorus Pools in Chilean Volcanic Soils as a Basis for Arbuscular Mycorrhizal Management in Plant P Acquisition. J. Soil Sci. Plant Nutr. 2019, 19, 390-401. [CrossRef]

18. Paredes, C.; Menezes-Blackburn, D.; Cartes, P.; Gianfreda, L.; Mora, M.L. Phosphorus and nitrogen fertilization effect on phosphorus uptake and phosphatase activity in ryegrass and tall fescue grown in a Chilean Andisol. Soil Sci. 2011, 176, 245-251. [CrossRef]

19. Mora, M.L.; Cartes, P.; Demanet, R.; Cornforth, I.S. Effects of lime and gypsum on pasture growth and composition on an acid Andisol in Chile, South America. Commun. Soil Sci. Plant Anal. 2002, 33, 2069-2081. [CrossRef]

20. Jorquera, M.A.; Hernández, M.T.; Rengel, Z.; Marschner, P.; Mora, M.L. Isolation of culturable phosphobacteria with both phytate-mineralization and phosphate-solubilization activity from the rhizosphere of plants grown in a volcanic soil. Biol. Fertil. Soils 2008, 44, 1025-1034. [CrossRef]

21. Osorio, N.W.; Habte, M. Soil Phosphate Desorption Induced by a Phosphate-Solubilizing Fungus. Commun. Soil Sci. Plant Anal. 2014, 45, 451-460. [CrossRef]

22. Calabi-Floody, M.; Velásquez, G.; Gianfreda, L.; Saggar, S.; Bolan, N.; Rumpel, C.; Mora, M.L. Improving bioavailability of phosphorous from cattle dung by using phosphatase immobilized on natural clay and nanoclay. Chemosphere 2012, 89, 648-655. [CrossRef] [PubMed]

23. Jara, A.A.; Violante, A.; Pigna, M.; Mora, M.L. Mutual Interactions of Sulfate, Oxalate, Citrate, and Phosphate on Synthetic and Natural Allophanes. Soil Sci. Soc. Am. J. 2006, 70, 337-346. [CrossRef]

24. Vistoso, E.; Theng, B.K.G.; Bolan, N.S.; Parfitt, R.L.; Mora, M.L. Competitive sorption of molybdate and phosphate in Andisols. J. Soil Sci. Plant Nutr. 2012, 12, 59-72. [CrossRef]

25. Cartes, P.; Cea, M.; Violante, A.; Mora, M.L.; Jara, A. Description of mutual interactions between silicon and phosphorus in Andisols by mathematical and mechanistic models. Chemosphere 2015, 131, 117-164. [CrossRef] [PubMed]

26. Vistoso, E.M.; Bolán, N.S.; Theng, B.K.G.; Mora, M.L. Kinetics of Molybdate and Phosphate Sorption by Some Chilean Andisols. Rev. Cienc. Suelo Nutr. Veg. 2009, 9, 55-68. [CrossRef]

27. Pigna, M.; Jara, A.A.; Mora, M.L.; Violante, A. Effect Of pH, Phosphate and/or Malate on Sulfate Sorption on Andisols. Rev. Cienc. Suelo Nutr. Veg. 2007, 7, 62-73. [CrossRef]

28. Xiong, J.; Wang, Y.; Xue, Q.; Wu, X. Synthesis of highly stable dispersions of nanosized copper particles using L-ascorbic acid. Green Chem. 2011, 13, 900-904. [CrossRef]

29. Siéwé, J.M.; Djoufac Woumfo, E.; Djomgoue, P.; Njopwouo, D. Activation of clay surface sites of Bambouto's Andosol (Cameroon) with phosphate ions: Application for copper fixation in aqueous solution. Appl. Clay Sci. 2015, 114, 31-39. [CrossRef]

30. Khatoon, H.; Solanki, P.; Narayan, M.; Tewari, L. Role of microbes in organic carbon decomposition and maintenance of soil ecosystem. Int. J. Chem. Stud. 2017, 5, 1648-1656. 
31. Dick, W.A.; Tabatabai, M.A. An Alkaline Oxidation Method for Determination of Total Phosphorus in Soils. Am. Soc. Agron. 1976, 41, 501-514. [CrossRef]

32. Murphy, J.; Riley, J.P. A modified single solution method for the determination of phosphate in natural waters. Anal. Chim. Acta 1962, 27, 31-36. [CrossRef]

33. Sadzawka, R.A.; Carrasco, R.M.A.; Grez, Z.R.; Mora, M.L.; Flores, P.H.; Neaman, A. Métodos de Análisis Recomendados Para Suelos Chilenos; Comisión de Normalización y Acreditación (CNA), Sociedad Chilena de la Ciencia del Suelo: Santiago, Chile, 2006.

34. Silva-Yumi, J.; Escudey, M.; Gacitua, M.; Pizarro, C. Kinetics, adsorption and desorption of Cd (II) and Cu (II) on natural allophane: Effect of iron oxide coating. Geoderma 2018, 319, 70-79. [CrossRef]

35. Lin, J.; Wang, L. Comparison between linear and non-linear forms of pseudo-first-order and pseudo-second-order adsorption kinetic models for the removal of methylene blue by activated carbon. Front. Environ. Sci. Eng. China 2009, 3, 320-324. [CrossRef]

36. Febrianto, J.; Kosasih, A.N.; Sunarso, J.; Ju, Y.H.; Indraswati, N.; Ismadji, S. Equilibrium and kinetic studies in adsorption of heavy metals using biosorbent: A summary of recent studies. J. Hazard. Mater. 2009, 162, 616-645. [CrossRef]

37. Wang, J.; Guo, X. Adsorption isotherm models: Classification, physical meaning, application and solving method. Chemosphere 2020, 258, 127279. [CrossRef]

38. Eduah, J.O.; Nartey, E.K.; Abekoe, M.K.; Weck Henriksen, S.; Neumann Andersen, M. Mechanism of orthophosphate (PO4-P) adsorption onto different biochars. Environ. Technol. Innov. 2019, 17, 100572-100583. [CrossRef]

39. Rawajfih, Z.; Nsour, N. Adsorption of $\gamma$-picoline onto acid-activated bentonite from aqueous solution. Appl. Clay Sci. 2010, 47, 421-427. [CrossRef]

40. Ghodszad, L.; Reyhanitabar, A.; Oustan, S. Biochar effects on phosphorus sorption-desorption kinetics in soils with dissimilar acidity. Arab. J. Geosci. 2021, 14, 366-383. [CrossRef]

41. Zhang, B.; Chen, N.; Feng, C.; Zhang, Z. Adsorption for phosphate by crosslinked/non-crosslinked-chitosan-Fe (III) complex sorbents: Characteristic and mechanism. Chem. Eng. J. 2018, 353, 361-372. [CrossRef]

42. Giles, C.H.; Macewan, T.H.; Nakhwa, S.N.; Smit, D. 786. Studies in adsorption. Part XI. A System of Classi\$cation of Solution Adsorption Isotherms, and its Use in Diagnosis of Adsorption Mechanisms and in Measurement of Specific Surface Areas of Solids. J. Chem. Soc. 1960, 846, 3973-3993. [CrossRef]

43. Limousin, G.; Gaudet, J.P.; Charlet, L.; Szenknect, S.; Barthès, V.; Krimissa, M. Sorption isotherms: A review on physical bases, modeling and measurement. Appl. Geochem. 2007, 22, 249-275. [CrossRef]

44. Mermoz, S.J.; Emmanuel, D.W.; Dieudonne, B.; Francois, F.; Paul, D.; Daniel, N.; Tamfuh, A.P. Andosols of the Bambouto Mountains (West Cameroon): Characteristics, Superficial Properties-Study of the Phosphate Ions Adsorption. Open Inorg. Chem. J. 2008, 2, 106-115. [CrossRef]

45. Yang, X.; Chen, X.; Yang, X. Effect of organic matter on phosphorus adsorption and desorption in a black soil from Northeast China. Soil Tillage Res. 2019, 187, 85-91. [CrossRef]

46. Fink, J.R.; Inda, A.V.; Bavaresco, J.; Barrón, V.; Torrent, J.; Bayer, C. Adsorption and desorption of phosphorus in subtropical soils as affected by management system and mineralogy. Soil Tillage Res. 2016, 155, 62-68. [CrossRef]

47. Zain, N.M.; Stapley, A.G.F.; Shama, G. Green synthesis of silver and copper nanoparticles using ascorbic acid and chitosan for antimicrobial applications. Carbohydr. Polym. 2014, 112, 195-202. [CrossRef]

48. Kobayashi, Y.; Ishida, S.; Ihara, K.; Yasuda, Y.; Morita, T.; Yamada, S. Synthesis of metallic copper nanoparticles coated with polypyrrole. Colloid Polym. Sci. 2009, 287, 877-880. [CrossRef]

49. Kobayashi, Y.; Sakuraba, T. Silica-coating of metallic copper nanoparticles in aqueous solution. Colloids Surfaces a Physicochem. Eng. Asp. 2008, 317, 756-759. [CrossRef]

50. Njoki, P.N. Transformation of Silver Nanoparticles in Phosphate Anions: An Experiment for High School Students. J. Chem. Educ. 2019, 96, 546-552. [CrossRef]

51. Calabi-Floody, M.; Bendall, J.S.; Jara, A.A.; Welland, M.E.; Theng, B.K.G.; Rumpel, C.; Mora, M.L. Nanoclays from an Andisol: Extraction, properties and carbon stabilization. Geoderma 2011, 161, 159-167. [CrossRef]

52. Krause, L.; Rodionov, A.; Schweizer, S.A.; Siebers, N.; Lehndorff, E.; Klumpp, E.; Amelung, W. Microaggregate stability and storage of organic carbon is affected by clay content in arable Luvisols. Soil Tillage Res. 2018, 182, 123-129. [CrossRef]

53. Gerke, J. Humic (organic matter)-Al (Fe)-phosphate complexes: An underestimated phosphate form in soils and source of plant-available phosphate. Soil Sci. 2010, 175, 417-425. [CrossRef]

54. Hoppe, M.; Mikutta, R.; Kaufhold, S.; Utermann, J.; Duijnisveld, W.; Wargenau, E.; Fries, E.; Guggenberger, G. Retention of sterically and electrosterically stabilized silver nanoparticles by soil minerals. Eur. J. Soil Sci. 2016, 67, 573-582. [CrossRef]

55. Nafiu, A. Effects of soil properties on the kinetics of desorption of phosphate from Alfisols by anion-exchange resins. J. Plant Nutr. Soil Sci. 2009, 172, 101-107. [CrossRef]

56. Zeng, L.; Johnson, R.L.; Li, X.; Liu, J. Phosphorus removal from aqueous solutions by sorption on two volcanic soils. Can. J. Soil Sci. 2011, 83, 547-556. [CrossRef]

57. Debicka, M.; Kocowicz, A.; Weber, J.; Jamroz, E. Organic matter effects on phosphorus sorption in sandy soils. Arch. Agron. Soil Sci. 2015, 62, 840-855. [CrossRef]

58. Hirsch, F.; Bonhage, A.; Bauriegel, A.; Schneider, A.; Raab, T.; Raab, A.; Gypser, S. The occurrence, soil parameters and genesis of rubified soils ('Fuchserden') of northeastern Germany. Catena 2019, 175, 77-92. [CrossRef] 
59. Cáceres-Jensen, L.; Rodríguez-Becerra, J.; Parra-Rivero, J.; Escudey, M.; Barrientos, L.; Castro-Castillo, V. Sorption kinetics of diuron on volcanic ash derived soils. J. Hazard. Mater. 2013, 261, 602-613. [CrossRef]

60. Parfitt, R.L. Phosphate reactions with natural allophane, ferrihydrite and goethite. J. Soil Sci. 1989, 40, 359-369. [CrossRef]

61. Zhou, A.; Tang, H.; Wang, D. Phosphorus adsorption on natural sediments: Modeling and effects of $\mathrm{pH}$ and sediment composition. Water Res. 2005, 39, 1245-1254. [CrossRef]

62. Li, R.; Wang, J.J.; Zhou, B.; Awasthi, M.K.; Ali, A.; Zhang, Z.; Gaston, L.A.; Lahori, A.H.; Mahar, A. Enhancing phosphate adsorption by $\mathrm{Mg} / \mathrm{Al}$ layered double hydroxide functionalized biochar with different $\mathrm{Mg} / \mathrm{Al}$ ratios. Sci. Total Environ. 2016, 559, 121-129. [CrossRef] [PubMed]

63. Duncan, E.; Owens, G. Metal oxide nanomaterials used to remediate heavy metal contaminated soils have strong effects on nutrient and trace element phytoavailability. Sci. Total Environ. 2019, 678, 430-437. [CrossRef]

64. Sun, W.; Jiang, B.; Wang, F.; Xu, N. Effect of carbon nanotubes on Cd (II) adsorption by sediments. Chem. Eng. J. 2015, 264, 645-653. [CrossRef]

65. Afshinnia, K.; Baalousha, M. Effect of phosphate buffer on aggregation kinetics of citrate-coated silver nanoparticles induced by monovalent and divalent electrolytes. Sci. Total Environ. 2017, 581-582, 268-276. [CrossRef] [PubMed]

66. Niaura, G.; Gaigalas, A.K.; Vilker, V.L. Surface-enhanced Raman spectroscopy of phosphate anions: Adsorption on silver, gold, and copper electrodes. J. Phys. Chem. B 1997, 101, 9250-9262. [CrossRef]

67. White, P.; Hjortkjaer, J. Preparation and characterisation of a stable silver colloid for SER(R)S spectroscopy. J. Raman Spectrosc. 2014, 45, 32-40. [CrossRef]

68. Cornelis, G.; Doolette Madeleine Thomas, C.; McLaughlin, M.J.; Kirby, J.K.; Beak, D.G.; Chittleborough, D. Retention and Dissolution of Engineered Silver Nanoparticles in Natural Soils. Soil Sci. Soc. Am. J. 2012, 76, 891-902. [CrossRef]

69. Pérez-Novo, C.; Fernández-Calviño, D.; Bermúdez-Couso, A.; López-Periago, J.E.; Arias-Estévez, M. Influence of phosphorus on Cu sorption kinetics: Stirred flow chamber experiments. J. Hazard. Mater. 2011, 185, 220-226. [CrossRef]

70. Liu, R.; Zhao, D. In situ immobilization of Cu (II) in soils using a new class of iron phosphate nanoparticles. Chemosphere 2007, 68, 1867-1876. [CrossRef]

71. Zhang, H.; Wang, J.N.; Zhu, Y.G.; Zhang, X. Research and application of analytical technique on $\delta 18$ Opof inorganic phosphate in soil. Chin. J. Anal. Chem. 2015, 43, 187-192. [CrossRef]

72. Zhou, W.; Liu, Y.-L.; Stallworth, A.M.; Ye, C.; Lenhart, J.J. Effects of pH, Electrolyte, Humic Acid, and Light Exposure on the Long-Term Fate of Silver Nanoparticles. Environ. Sci. Technol. 2016, 50, 12214-12224. [CrossRef] [PubMed]

73. Funakawa, S.; Hirooka, K.; Yonebayashi, K. Temporary storage of soil organic matter and acid neutralizing capacity during the process of pedogenetic acidification of forest soils in Kinki District, Japan. Soil Sci. Plant Nutr. 2008, 54, 434-448. [CrossRef]

74. Poggere, G.C.; Melo, V.F.; Serrat, B.M.; Mangrich, A.S.; França, A.A.; Corrêa, R.S.; Barbosa, J.Z. Clay mineralogy affects the efficiency of sewage sludge in reducing lead retention of soils. J. Environ. Sci. 2019, 80, 45-57. [CrossRef] [PubMed]

75. Yan, L.G.; Xu, Y.Y.; Yu, H.Q.; Xin, X.D.; Wei, Q.; Du, B. Adsorption of phosphate from aqueous solution by hydroxy-aluminum hydroxy-iron and hydroxy-iron-aluminum pillared bentonites. J. Hazard. Mater. 2010, 179, 244-250. [CrossRef]

76. Trinh, V.T.; Nguyen, T.M.P.; Van, H.T.; Hoang, L.P.; Nguyen, T.V.; Ha, L.T.; Vu, X.H.; Pham, T.T.; Nguyen, T.N.; Quang, N.V.; et al. Phosphate Adsorption by Silver Nanoparticles-Loaded Activated Carbon derived from Tea Residue. Sci. Rep. 2020, 10, 1-13. [CrossRef] [PubMed]

77. Bulmer, D.; Hamilton, J.; Kar, G.; Dhillon, G.; Si, B.C.; Peak, D. Effects of Citrate on the Rates and Mechanisms of Phosphate Adsorption and Desorption on a Calcareous Soil. Soil Sci. Soc. Am. J. 2019, 83, 332-338. [CrossRef]

78. Liu, Z.; Zhang, Y.; Han, F.; Yan, P.; Liu, B.; Zhou, Q.; Min, F.; He, F.; Wu, Z. Investigation on the adsorption of phosphorus in all fractions from sediment by modified maifanite. Sci. Rep. 2018, 8, 1-13. [CrossRef]

79. Jung, H.B.; Xu, H.; Konishi, H.; Roden, E.E. Role of nano-goethite in controlling U(VI) sorption-desorption in subsurface soil. J. Geochem. Explor. 2016, 169, 80-88. [CrossRef]

80. Elkhatib, E.; Moharem, M.; Mahdy, A.; Mesalem, M. Sorption, Release and Forms of Mercury in Contaminated Soils Stabilized with Water Treatment Residual Nanoparticles. Land Degrad. Dev. 2017, 28, 752-761. [CrossRef] 